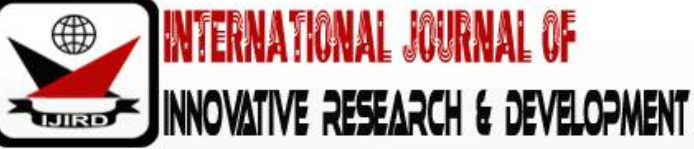

ISSN 2278 - 0211 (Online)

\section{Mainstreaming "Adaptive Standards for Multi-Purpose Interior Design" In Low-Cost Housing Projects: A Case Study of the Kibera Soweto East Housing Project in Nairobi, Kenya}

\author{
Grace Wawira Njeru \\ Masters Student, School of the Arts and Design, University of Nairobi, Kenya \\ Dr. Samuel M. Maina \\ Senior Lecture, School of the Arts and Design, University of Nairobi, Kenya \\ Dr. Michael Munene \\ Lecture, School of the Arts and Design, University of Nairobi, Kenya
}

\begin{abstract}
:
The Kibera Soweto East Housing Project was developed under the Kenya Slum Upgrading Programme (KENSUP) whose main objective was to improve the housing conditions of the residents of Kibera through the construction of 822 low-cost formal houses. However, phase one did not take into consideration the adaptive standards for multi-purpose room occupancy as prescribed under the KS Building Code, 2009 thus negatively impacting the recommended habitability standards of the Kenya Slum Upgrading Programme. This study therefore sought to establish the adaptive standards for multi-purpose interior design in Kenya as well as assess the extent to which the Kenya Slum Upgrading Programme has applied them. The research design was the case study model where the research employed the collection and analysis of qualitative data obtained through examination of documents, interviews and observations. The study was carried out at The Kibera Soweto East Housing Project, Kenya and its residents plus the professionals involved in the project as the respondents. The output was the recommendation of three strategies for the improvement of future slum upgrading housing programme which include employment of the open plan concept by combining the living room and kitchen into one big space, elimination of corridors to create more space for other rooms and installation of sliding doors instead of hinged doors. When spaces created for low-cost housing are not up to standard as prescribed under the code, the living standards and quality of life and of the residents living in these particular houses are negatively affected.
\end{abstract}

Keywords: Adaptive standards, furniture layout, low-cost housing and multi-purpose

\section{Introduction}

\subsection{Background}

In 1992, an adaptive standard for 'multi-purpose room occupancy' was first constituted as part of Code 92 by the Inter- Ministerial Task Force in Kenya. It was later gazettted as code 95, in 1995. The standard applying to a multi-purpose room (i.e. single room occupancy) was 10.50 sq. m. which has been carried forward to the current KS Building Code, 2009. Further standards are prescribed for other spaces such as the kitchen, bathroom and toilet. These adaptive standards have been applied to single-storey tenements in different appears but the County of Nairobi has not yet made significant effort to apply this code, nor has the Ministry of Lands and Housing in The Kenya Slum Upgrading Programme. The KS Building Code, 2009 did not foresee multi-storey rooming, as a result, it does not have any standards for the number of rooms that should be provided in one building as well as standards for the access of air-wells, balustrades, balconies, staircase, corridors and so much more. However, the code does make provision for a Building Code Review Board to keep under review all the building bylaws and provisions in Kenya to ensure their applicability and relevance to the development of safe, sanitary and affordable housing as well as other urban facilities.This review board was never created, however, it could play a significant role in establishing suitable, non-displacing standards of habitability for slum upgrading (Huchzermeyer, 2008).

Until September of 2010, Kibera was regarded as the second largest slum in Africa following South Africa. It records a population of 170,070 according to the Kenya Population and Housing Census of 2009 (Daily Nation, 2010). The neighborhood is divided into 13 villages, including Mashimoni, Laini Saba, Lindi, Kisumu Ndogo, Gatwekera, Kianda, Makina, Soweto East and Siranga. A UN-HABITAT socio-economic account indicates that Soweto East has a population of 19,318 spread out in four major zones namely; A, B, C and D. Zone A is the biggest with an area of 6.9 hectares and accounts for $37 \%$ of the houses in Soweto East. It has 876 structures and a population of 6,288. Out of the 6,288, about $90 \%$ are occupants and only $10 \%$ of them are landlords, who don't reside in the area but collect a monthly rent from the 
tenants and use the processed to construct houses in other parts of Nairobi (UN-HABITAT, 2008). This therefore indicates that on average, each house is inhabited by seven residents which is quite high in comparison to that of a residential unit in Nairobi which has an average of four occupants. This area is considered ideal to construct houses since its relatively close to the Central Business District (CBD),the health sector, for example, Kenyatta National Hospital, Angelic Mission Hospital and Mbagathi Hospital; upper hill area, the large industrial area and the affluent neighborhoods of Kilimani, Lang'ata or the middle-class neighborhoods of Nairobi West or South $\mathrm{C}$ hence making it a residential area best fit for workers, artisans and minor functionaries (Rosa \& Bernard, 2012).

The Government of Kenya, in collaboration with UN-HABITAT and other stakeholders, initiated the Kenya Slum Upgrading Programme (KENSUP) in 2004 whose main mandate is to upgrade lives and livelihoods of people living as well as working in the slum areas through a number of initiatives and interventions. The Kenya Slum Upgrading Programme addresses national aspirations as specified in the Bill of Rights of the Constitution and Vision 2030. It as well as facilitates the achievement of the Millennium Development Goals, specifically, goal seven target eleven on upgrading the living standards of at least a hundred million slum inhabitants in worldwide by the end of year 2020. This entails introduction of money making activities, facilitating security of tenure, community as well as resource mobilization, installation of both social and physical infrastructure, construction of low cost houses, solid waste and environment management, capacity building among the communities and tackling key ailments such as alcohol, substance and drug abuse, insecurity, HIV and AIDs(State Department of Housing and Urban Development, 2017).

\subsection{Profile of The Kibera Soweto Housing Project}

It was a project developed under the Kenya Slum Upgrading Programme (KENSUP); whose main mandate was to upgrade the housing conditions of the residents of Kibera through the construction of 822 low-cost formal houses. It was launched in 2012 and the handing over ceremony of the completed houses took place on the $8^{\text {th }}$ of July 2016.The apartments comprise of a living room, bedroom(s), kitchen, bathroom and toilet. The area of the living room for the onebedroom house is $8.12 \mathrm{sq}$. $\mathrm{m}$. while that for the two-bedroom house is $9.30 \mathrm{sq}$. $\mathrm{m}$. The area of the bedroom for the onebedroom house is 7.56 sq. $\mathrm{m}$. while those for the two-bedroom house is $8.40 \mathrm{sq} . \mathrm{m}$. The area of the kitchen for the onebedroom house is 2.66 sq. $\mathrm{m}$. while that for the two-bedroom house is 2.94 sq. $\mathrm{m}$.

\subsection{Problem Statement}

The Kibera Soweto East Housing Project, Phase One did not take into consideration the adaptive standards for multi-purpose room occupancy as prescribed under The KS Building Code 2009 thus negatively impacting on the recommended habitability standards of the Kenya Slum Upgrading Programme.

\subsection{Research Questions}

- What are the adaptive standards for multi-purpose interior design in Kenya?

- How has the Kenya Slum Upgrading Programme (KENSUP) applied the adaptive standards for multi-purpose interior design in Kenya?

- What are the recommended strategies for the total implementation of adaptive standards for the improvement of future slum upgrading housing programme?

\subsection{Objectives of the Study}

- To establish the adaptive standards for multi-purpose interior design in Kenya.

- To assess the extent to which the Kenya Slum Upgrading Programme (KENSUP) has applied the adaptive standards for multi-purpose interior design in Kenya.

- To recommend strategies for the total implementation of adaptive standards for the improvement of future slum upgrading housing programme.

\subsection{Geographical Scope of the Study}

The Kibera Soweto East Housing Project is a five-acre estate comprising of 21 blocks of five floors each. The apartments comprise of 144 units with three rooms, 570 units with two rooms and 108 units with a single room. It is located in Lang'ata area, southwest of Nairobi and approximately 6.6 kilometers from Nairobi City Centre as shown in Figures 1 to 4 in the following pages. 


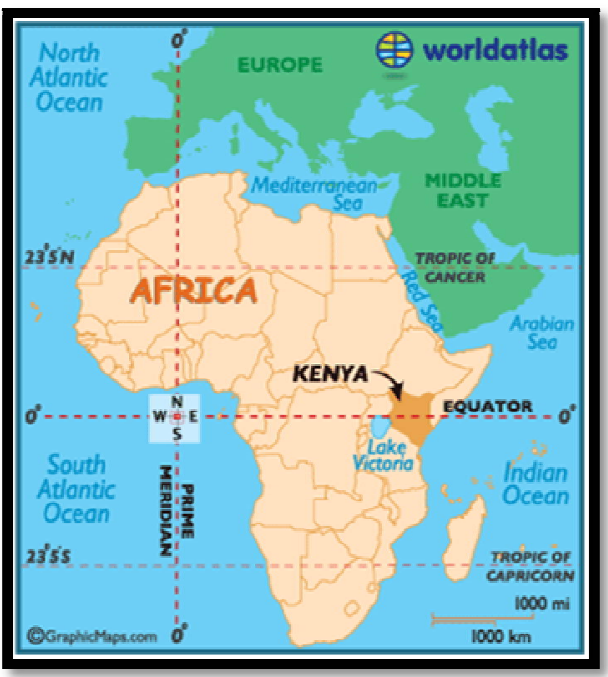

Figure 1: Geographical Location of Kenya Source: www.worldatlas.com

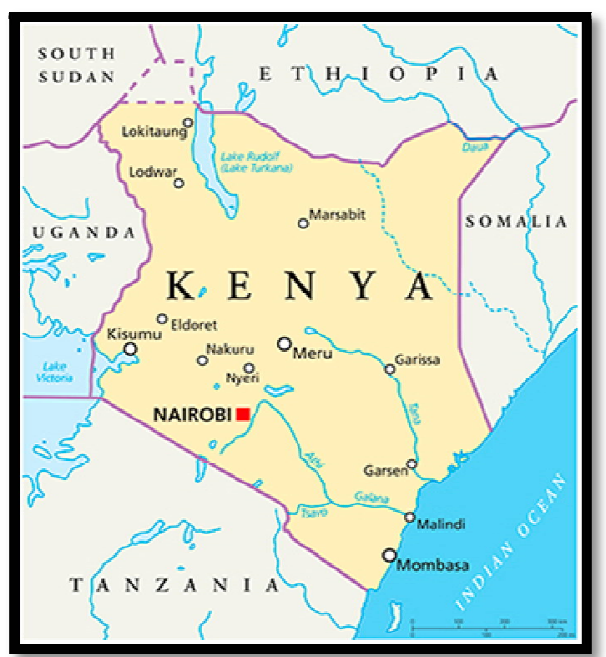

Figure 1: Geographical Location of Nairobi, Kenya Source: http:/ / sph.berkeley.edu

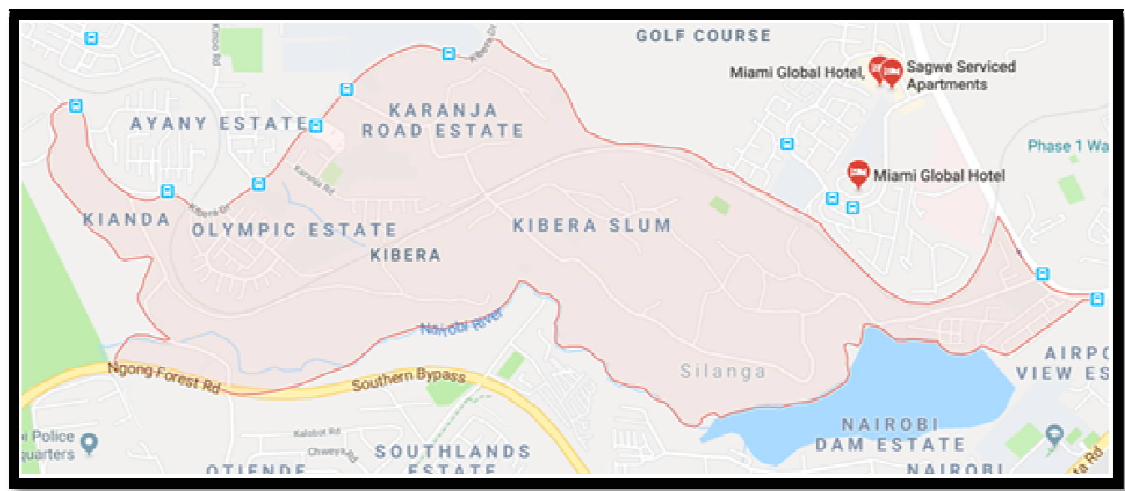

Figure 2: Geographical Location of Kibera, Lang'ata District Nairobi Source: Https:/ / Digit.Hbs.Org) 


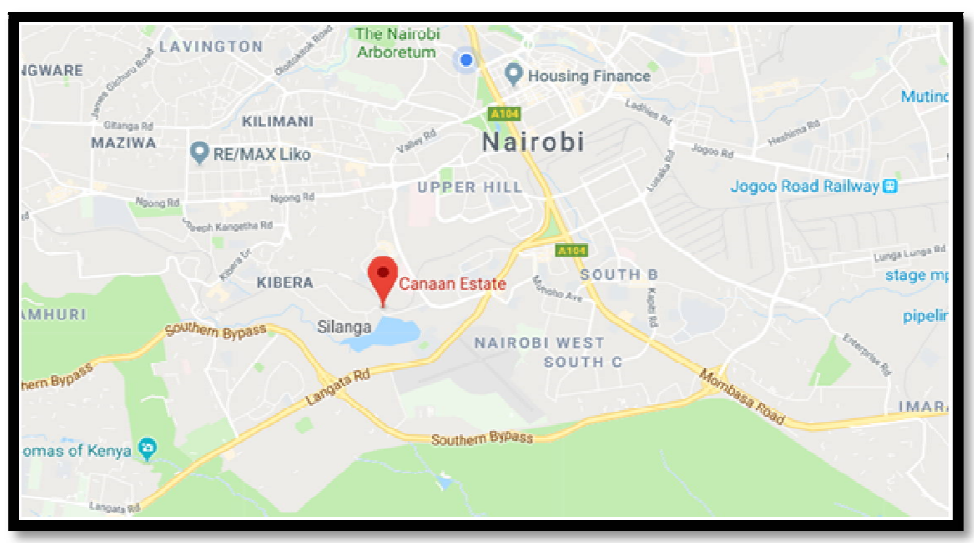

Figure 3: Geographical Location of the Kibera Soweto East

Housing Project in Canaan Estate

Source: http:// sph.berkeley.edu

\subsection{Contextual Scope of the Study}

It focuses on low-cost housing developed for the low-income earners who reside in the informal settlements; mainly those which are developed by the local government and whose aim is towards slum upgrading.

\subsection{Conceptual Scope of the Study}

It confines itself to multi-purpose interior design in Kenya, its application by the Kenya Slum Upgrading Programme (KENSUP) as well as the relevant key players such as the residents of the Kibera Soweto East Housing Project and the professionals involved in the success of the project such as architects, electrical engineers, quantity surveyors, mechanical engineers, contractors and plumbers.

\subsection{Significance of the Study}

This study is of great importance since the recommended building standards will be applied to the other housing units that the government seeks to construct in Zone B, C and D of Soweto East, Kibera. It may also act as a guideline to the government and private sector, to be used when coming up with future projects for low-cost housing in other parts of Kenya. In the long run, this will see an improvement of living standards and quality of life of not only residents of Soweto East, Zone A but of other Kenyan citizens. The findings of this study will also enrich existing knowledge and therefore will be of great interest to both academicians and researchers who desire to explore and carry out further investigations.

\subsection{Limitations of the Study}

Limitations include resistance from some of the Kibera residents to participate in the research and most of them denying the researcher access to their houses. In addition, most of the residents speak Kiswahili which requires translation for easier analysis of results. The research also requires presentation of documents from the relevant authorities that the researcher is allowed carry out research in their premises and also initiating a good rapport with the correspondents before carrying out the research. Another limitation is difficulty in getting to interview some of the professionals involved in the success of the project. Prior interview arrangements were done with the professionals. In addition, most interviews were scheduled around the same period.

\subsection{Definition of Terms}

\subsubsection{Slum Upgrading}

It's the process by which informal settlements, are progressively improved, formalized and ultimately assimilated into the city through the provision of citizenship to slum residents, social services and secured land tenure.

\subsubsection{Low- Cost Housing}

It's housing that's meant for the middle-low income group in the society. It's justifiably sufficient in standard and location and can either be provided by the private housing associations or the local government authorities, aiding to assist those who cannot access housing in the private rental market. In Kenya, it may be sold at or close to Ksh. 1 million (Van Noppen, 2012).

\subsubsection{Low Income Earners}

In the Kenyan context, they are individuals who earn Ksh. 50,000 and below per month (Institute of Economic Affairs, 2015).

\subsubsection{Habitable Room}

It's a room designed or used for human habitation and includes any living room, workroom, office or any other room adapted, used or designed for the intent of eating, sleeping or cooking therein, or as a place for the habitual employment of any person. 


\subsubsection{Occupancy}

It's the specific use or the type of use to which a building or a portion of it is normally put or intended to be put.

\subsubsection{Slums}

They are abandoned sections of a city were the living standards and housing are very deficient. They are referred to in a number of ways and have the same deplorable living conditions. (Global Report on Human Settlements Revised $2010,10)$.

\section{Literature review}

\subsection{Introduction}

Housing is a set of long-lasting assets, which accounts for a high percentage of a country's resources and on which households spend a considerable part of their earnings (HoekSmit, 2011). In the case of low income earners, they spend o good portion of their income on housing than high income earners (UNCHS, 1996). In most developing countries like Kenya, the low income earners form the larger part of a country's population size hence most governments strive to house these particular set of people. This may be due to the fact that most developers have failed to come up with housing for this group of the society because they are not considered to be credit worthy for financing to have decent, affordable housing.

\subsection{Malaysia Low Cost Housing Project}

Malaysia is among the countries that has successful managed to incorporate well-designed interior plans and layouts in their low-cost housing projects; especially in Kuala Lumpur, Selangor, Peninsular and Klang Valley. Its dedication towards the construction of low-cost houses began during the First Malaysia Plan which ran from 1966 to 1970 while the private sector's participation came in during the Second Malaysia Plan which ran from 1971 to 1975. The Third Malaysia Plan ran from 1976 to 1980and saw the construction of the Low Cost Flats in Kuala Lumpur whose supervision was under the City Hall Kuala Lumpur (CHKL). It then continued to the Fourth Malaysia Plan which was from 1981 to 1985, Fifth Malaysia Plan which run from 1986 to 1990, Seventh Malaysia Plan which was from 1996 to 2000, Eight Malaysia Plan which run from 2001 to 2005 and Ninth Malaysia Plan which was from 2006 to 2010. Attention was towards the provision of standard, cost-effective and sufficient housing units for all Malaysia residents, particularly the low income earners. More emphasis was placed on the private sector to construct more low and low to medium cost houses in their mixed development projects while the public sector placed more emphasis on erecting low cost houses and housing for the public sector employees, underprivileged and deprived in rural and urban areas. The plan that is currently underway is the Tenth Malaysia Plan which began 2010 and is set to end in 2020. It mainly seeks to accommodate six million new residents in the urban areas, especially in Peninsular Malaysia (Ghani \& Lee, 1997).

The Local Government (Kementerian Perumahan dan Kerajaan Tempatan-KPKT) and Ministry of Housing via the National Housing Department (Jabatan Perumahan Negara -JPN) are sorely in charge of monitoring and managing the construction of public housing programs projects. Most of them have been implemented by the government amongst being Dimiliki Dasar Baru, Projek Perumahan Rakyat (PPR), Projek Perumahan Awam Kos Rendah (PAKR), Projek Perumahan Rakyat (PPR), Projek Perumahan Rakyat (PPR), Bersepadu (MTEN) and Disewa Dasar Baru.The public housing programmes falls under the social sector of the national strategy. Housing policies are categorized into three groups which are; The Colonial Housing Policy (1948-1960), Policy On Home-Owning Democracy (1961-1970) and Housing Policy (1976-1990).

A set of standards is in place for the interior planning and design of these low-cost houses. The floor space for the terrace house was $48-60$ sq. m. while that of the flats was $45-56$ sq.m. The Terrace Houses and flats was to have a minimum number of bedrooms being three with the first room having a minimum area of $11.70 \mathrm{sq}$. $\mathrm{m}$. the second room being $9.90 \mathrm{sq}$. $\mathrm{m}$. and the third room being $7.20 \mathrm{sq}$. $\mathrm{m}$. The kitchen's minimum area for both the terrace and flats was 4.5 sq. $\mathrm{m}$. The living and dining room for the terraces and flats had either to be amalgamated or segregated with ample area for both rooms. The bathroom and toilets for the terraces and flats were to be provided individually with the least area for each being $1.8 \mathrm{sq}$. $\mathrm{m}$. The flats and terraces' storage and foyer was to be designed in such a way that there was enough provision for resident's satisfaction and comfort (Idrus, Noraliah \& Chin 2008).

\subsection{South Africa Low Cost Housing Project}

Since 1994, efforts have been made to deliver affordable housing to about 2.3 million poor households through the project-linked housing subsidy scheme. The minimum size of the first low-cost housing at the time of construction covered a total area of 22 sq. m., while the later versions were slightly larger at 25 sq. m. In September 2004, there was the establishment of an Informal Settlement Upgrading Programme (ISUP) with a committed subsidy mechanism, as part of the larger refinement of the National Housing Policy in the form of a document called 'Breaking New Ground': A Comprehensive Plan for the Development of Sustainable Human Settlements. In its introduction, the Informal Settlement Upgrading Programme called for a paradigm shift in relation to informal settlement intervention. Its main objective was to wipe out all informal settlements by 2014 (Ziblim, 2013).

Among the projects undertaken by government include The Zwelisha Upgrade Project which started in year 2005. It is located $35 \mathrm{~km}$ north of Durban within the municipality of eThekwini. Beginning of the same year, almost 3000 households were moved from Zevenfontein informal settlement to a new housing development called Cosmo City. The National Housing Policies that the South Africa government had included; 
- The White Paper on Housing (1994) which prioritized the needs of the historically underprivileged South Africans and dedicated to provide one million housing units within five years.

- The Republic of South Africa Constitution (1996) which emphasized the government's devotion towards providing housing units for the destitute.

- The Social Housing Policy for South Africa (2003) which emphasized the government's readiness to create sustainable human settlements by providing good quality housing and an environment that is receptive to the demands of the target communities (Ganiyu, Haldenwang, \& Fapohunda, 2016).

The following general specification deals with the compulsory requirements stated in the regulations issued in terms of the Housing Consumers Protection Measures Act (Act No. 95 of 1998), the National Building Regulations and Building Standard Act, 1997 (Act 103 of 1977), and certain minimal requirements for houses constructed in terms of the subsidy housing scheme. It contains as well few optional requirements that will upgrade the housing quality. This common specifications were developed to interpret the standards and norms contained in the National Housing Code into quantitative requirements, consistent with applicable requirements of the National Home Builders Registration Council and the National Building Regulations. Compliance with the provisions of this inclusive specification will result in compliance with the technical requirements of the Building Standards Act, the Housing Consumers Protection Measures Act and the National Building Regulations in respect of the qualities that are covered by these pieces of legislation.

- The houses shall have a maximum length between intersecting walls or members providing lateral support of 6 meters.

- Window area should not surpass $15 \%$ of the total floor area.

- Floor area of a one-bedroom house, shall not be below 30.0 sq. m. based upon the general external plan dimensions.

- The floor area of a two-bedroom house, shall not be below 40.0 sq. m. based upon the general external plan dimensions, as indicated in Figure5 below.

- The floor area of a habitable room apart from the kitchen, shall not be below 6.0 sq. m. based on horizontal plan dimensions between un-plastered wall surfaces, excluding any area occupied by a built in cupboard or any diving panel or wall.

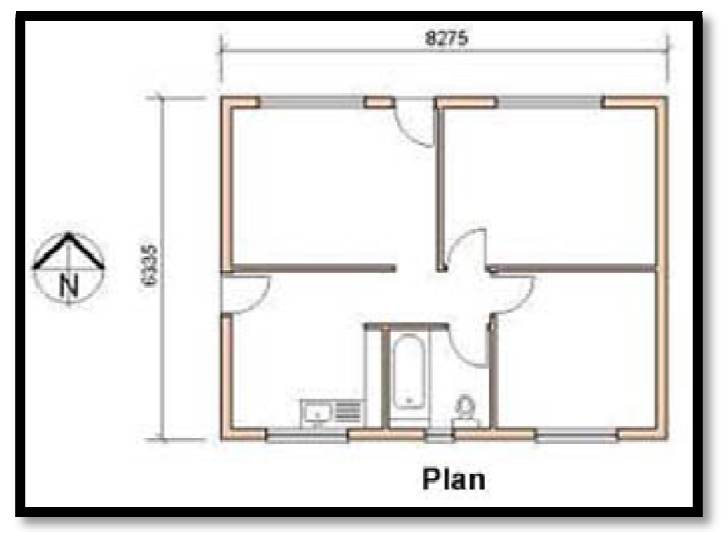

Figure 4: Two Bedroom House Plan Source: Gfsh-11, 2013

- The bedroom shall have a minimal height of 2.4 meters over a floor area that is not below 6 sq. m. with a clear height of at least 1.8 meters at any point more than 0.75 meter from the edge of the floor space.

- Any other habitable room shall have a minimum height of 2.4 meters, over a minimum of $70 \%$ of the floor area, and not less than 2.1meters over the remaining floor area.

- The shower-room, bathroom or room having a water closet pan shall have a minimal height of 2.1meters, over any area where a person would usually be standing (GFSH-11, 2013).

\subsection{KS Building Code (2009) of Kenya}

A building code also known as building regulations or controls, is a set of regulations that state the standards for constructed objects such as buildings and non-building structures. It is applied mostly to permanent structures in urban areas which are designed by professional architects and engineers according to established standards of modern construction practice. These structures must conform to the code to obtain planning permission which is normally obtained from the governing local council. The code becomes law of a specific jurisdiction when formally passed by the suitable private or governmental authority. However, the bulk of construction activity, especially in the residential sector and particularly for the low-income population, follows traditional construction practice, and this produces structures which fall outside the scope of most building legislation. (Ching, 2016).

There exist a number of codes which specify these guidelines depending on different countries. Currently, the Building Code of the Republic of Kenya; 2009 Edition is in force and is being regulated by the Local Government Authority and its content was revised from the then Code 95 which was developed by the Inter- Ministerial Task Force in 1995. It proposes the coming up with multi-purpose rooms and incremental houses that are more affordable for the low income earners; a majority of whom have a large family size with an average member number of seven unlike the middle-high income earners who have four members. It aims at enabling house and room standard sizes through reduction of building 
costs, encourage use of locally available resources and appropriate technology, promote innovative designs, and put emphasis on performance and functionality (KSBuilding Code, 2009).

It was envisaged that its implementation and enforcement would harmonize building works and physical planning; enhance collaboration, professionalism and accountability among professionals and other stakeholders in the construction industry; and more investment in the industry as a result of a firm and expected real estate market. The code is indeed vital in attaining sustainable, well planned, safe, decent, healthy and affordable housing. For a successful model, building code legal status and capacity should be executed so that it's embraced by all the stakeholders in the building industry. Unfortunately, it has become outdated in the face of many changes and oppositions that have emerged in the industry; and truth be told, it only exists on paper as the reality on the ground is that many constructions have not adhered to it (Rukwaro, 2012).

Building codes should provide minimum standards that should be adhered to ensure safety, building standards, security and health of the property from all hazards that may occur to the structure. It should also increase growth, control and transform housing sector and make good use of the available local materials without any constrains. The steps towards execution, adoption and popularizing codes of practice plays a pivotal role in life span of its existence. They serve as an instrument of guiding and reforming the building sector in any economy (Erastus, 2014).

\subsubsection{Multipurpose Room}

The overall plan area of any multipurpose room shall not go below 10.50 sq. m. as illustrated in Figures 6 and 7 below.

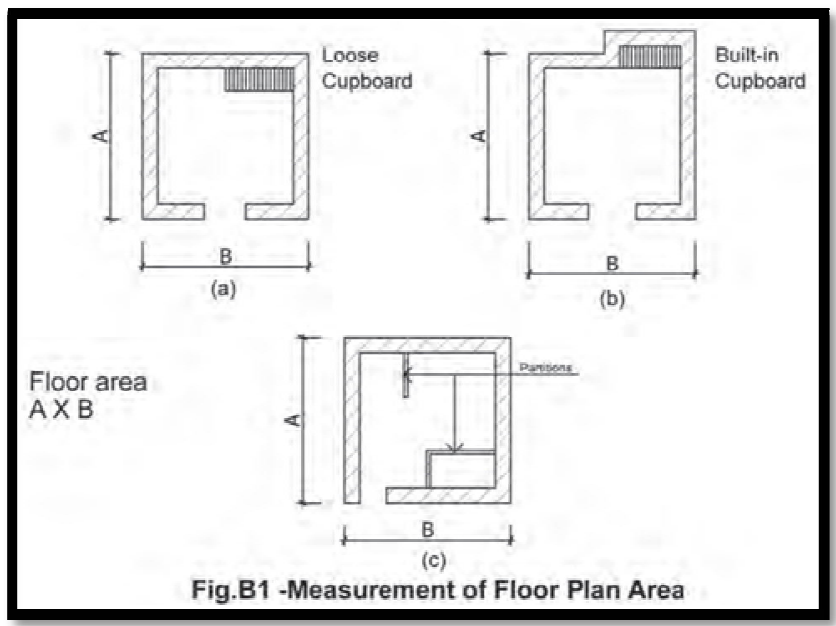

Figure 5: Measurement of Floor Plan Area

Source: Planning and Building Regulations, 2009

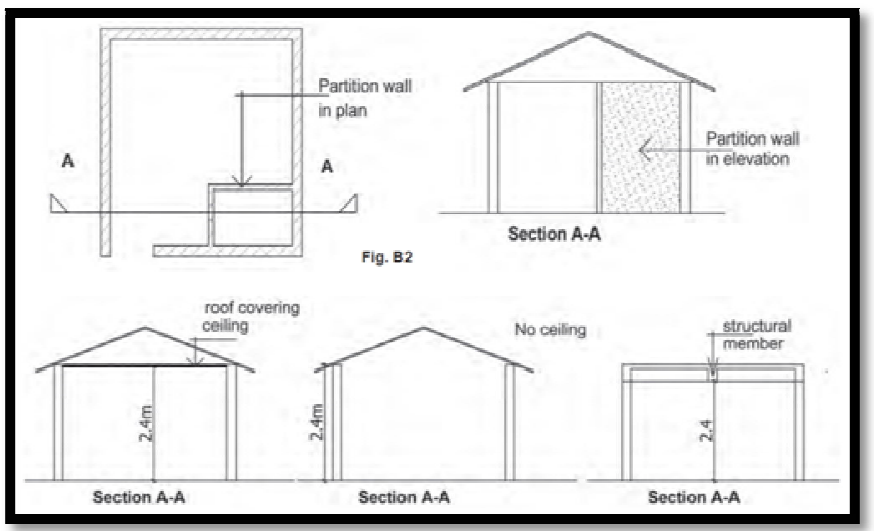

Figure 6: Partition Wall and Height of the Room

Source: Planning and Building Regulations, 2009

\subsubsection{Kitchen and Bathroom}

A kitchen shall be provided for every dwelling of more than two habitable rooms and shall have an area of not less than 3.30 sq. m. for plots up to 50 sq. $\mathrm{m}$. and $4.50 \mathrm{sq}$. m. for plots above 50 sq. m. with the minimal horizontal dimension of which shall be 1.82 meters. The ceiling to floor height of every kitchen shall not be less than 2.43 sq. m.A satisfactory means for cooking food, suitable sink, approved ventilation and lighting shall be provided for every kitchen. There shall be provided properly distinct cooking place in a dwelling having only one habitable room that is nothing short of $3.23 \mathrm{sq} . \mathrm{m}$. in area having a minimal dimension of 2.13 meters in height and 1.21 meters in depth. It shall have a sufficient outlet for fumes and smoke as well as be ventilated and lighted. The minimum requirement for bathroom in plots up to $50 \mathrm{sq}$. $\mathrm{m}$. is 1.20 sq. m. while that of above 50 sq. m. is 1.80 sq. m. as shown in Figure 8 below. 


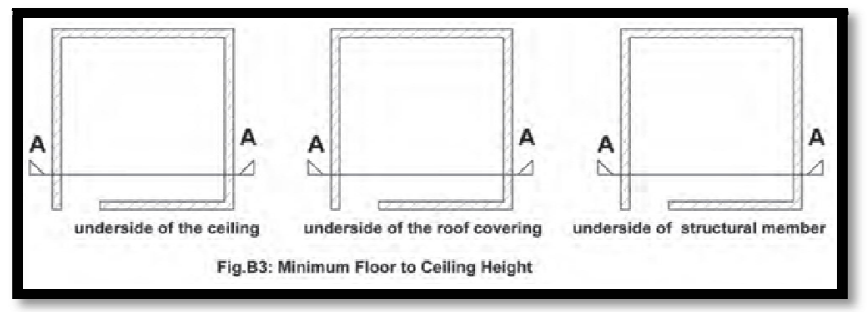

Figure 7: Minimum Floor to Ceiling Height

Source: Planning and Building Regulations, 2009

\subsubsection{Windows}

Adequate number of windows opening to the external air shall be provided for every habitable room; kitchen, roofed latrine and bathroom so as to provide a clear lighting area equal to at least one-tenth of the floor area of such room, and of which at least one-twentieth of the floor area shall be capable of being opened.

\subsection{Open Plan Space Concept for Low Cost Housing}

The open plan space concept was first implemented into the interiors of the low-cost housing in 1950 after the Second World War. This meant that the conventional division between rooms disappeared either through elimination or reduction of interior walls. This was so that the living room, kitchen and dining room could occupy one free flow of space, running from the back to the front of the house as illustrated inFigure9 below. The kitchen counter could then be used as a transition space between the spaces. This therefore meant that the open plan space included a sitting area with sofa-beds and extendable dining tables to accommodate for guests, as well as a large pantry and island within a fully accessible kitchen. This meant that within the same space, one could entertain guests, watch television, work with a computer, use the telephone, relax, prepare meals and dine with friends and family (Ward, 2017).

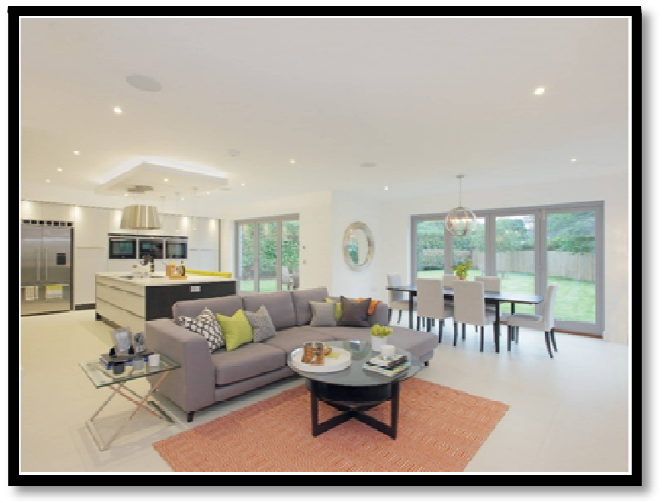

Figure 8: Open Plan Living Space

Source: www.self-build.co.uk

\subsection{Furniture Layout for Low Cost Housing}

Fay (2005) states that the interior plans and layouts for low-cost housing should be kept simple, regular/ standard and to a bare minimum so as to make the most of the available space and allow maximum repetition of interior elements such as fittings, fixtures and materials. This provides residents with the choice in the way they use space and arrange furniture with the aim of allowing their living patterns to be accommodated as their needs change over time. It also meets social needs by allowing inhabitants a degree of personal expression and it also ensures that housing has a long life. Lack of it thereof, denies them the opportunities for self-expression results in isolation and stigmatization.

In the case of Dolphin House, the furniture for each type of room is organized in three different configurations: circle, square, and line. Since floor and wall material can be customized, when multiple rooms are placed adjacent to each other and furniture styles are varied, room size, function, and materiality can be mixed throughout the house, generating a unique arrangement of rooms that can fit into almost any site condition. The systematic use of components allows users to fully control their spaces by deciding how to combine these parts to create a whole. Rather than piecing spaces together from various individual items at random, residents choose from cohesive units that, in conjunction with each other, create endless possibilities (Knezo, 2016).

\subsection{Efficient Interior Spaces for Low Cost Housing}

MacDonald (1996) designed a number of affordable house prototypes including a studio home for single people ('single parents, retired widows/widowers, young people, unmarried workers and those leading a lonely and unremunerated contemplative life'). This studio home is a single-story building with a ground floor area of 18.2 square meters and a loft of 5.8 square meters (below the pitched ceiling) that can be used for storage, a bed space, or work area, depending on local regulations. The dwelling in the ground floor area has basic furniture including a sofa bed, dining table for two people, and a number of storage units and has a bathroom, walk-in storage space, a large living-sleeping space with kitchen joinery along one wall and a niche at one end in which a prefabricated fireplace can be installed.One of the 
strategies that have been employed to make the small space appear larger than it is, is having high ceilings of 2.6 meters. This highlights the importance of design, especially if construction costs are to be reduced by keeping floor area to a minimum.

Efficient interior spaces can also be archived by providing quality finishes and detailing. By restricting the overall square footage of a house, more resources can be budgeted towards the purchase of materials, improving the finish quality and detailing to make a house exceptional. Reducing the size of the house may also be a method to include some of the "green" building products and materials that are pricier (natural granite countertops, linoleum, top-efficiency appliances, certified wood flooring etc.). Another strategy would be increased dwelling size, decreased housing specificity, allowance for change (walls to be removed, added or moved), provision of movable elements such as wardrobes, cupboards and walls and provision of developments containing a number of different types of units allowing residents to move as their needs change i.e. children no longer live at home (Boehland \& Wilson, 2005).

\subsection{Multi-Purpose Interior Spaces for Low Cost Housing}

Multi-purpose interior spaces are those spaces which can be used in variety of ways; generally without making any physical changes. This is primarily through the way the spaces are organized, the designation of rooms and the circulation patterns. Boehland, \& Wilson, (2005) suggests combining functions of different rooms for space optimization. For example: combining a home office with a guest bedroom and provision for both music functions and television viewing in the living room. Hartany \& Le (n.d) developed The Gio Ponti Project as shown in Figure10 below, with the idea of a single space that is surrounded by vital minimum of services, that is, cookery and washrooms that are thrust to opposite sides of the single large space. A series of angles sections of wall provide the connecting point for concertina panels. These walls allow the creation of different connections between different areas and keep the aspect of them being multi-purpose.

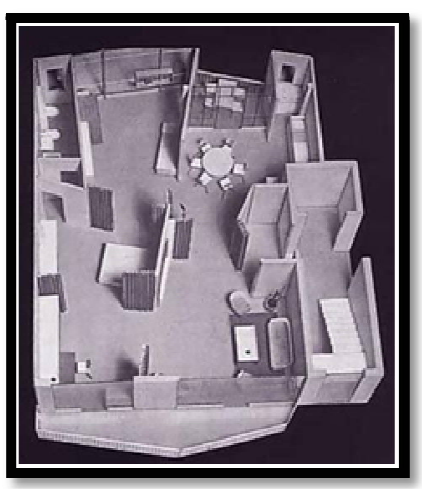

Figure 9: The Gio Ponti Project

Source: Www.Pinterest.Com

Vander Rohe achieves multi-purpose in interior spaces by only building the circumference walls and two columns within, which holds the ceiling and the rest is as open as it can be. He proceeds to produce cheap plywood walls then later designs the cookery and washroom as immovable rooms and the rest of the space as varying dwelling space so that he is able to split these spaces according to the needs of the occupants. This would also have advantages insofar as it would provide the likelihood to change the layout of a unit according to changes within a family, without large modification costs. Any joiner or down-to-earth laymen would be in the position to shift walls (Till \& Schneider, 2005).

2.9. Conceptual Framework

Conceptual framework as illustrated in Figure 11 is a symbolic and simplified demonstration which selects the variables that when placed together expound the issue of concern (Peters, Elmendorf, Kandola \& Chellaraj, 2000). It is a set of broad ideas used to elaborate the connection between the independent variables (factors) and the dependent variables (results) (Coulthard, 2004).

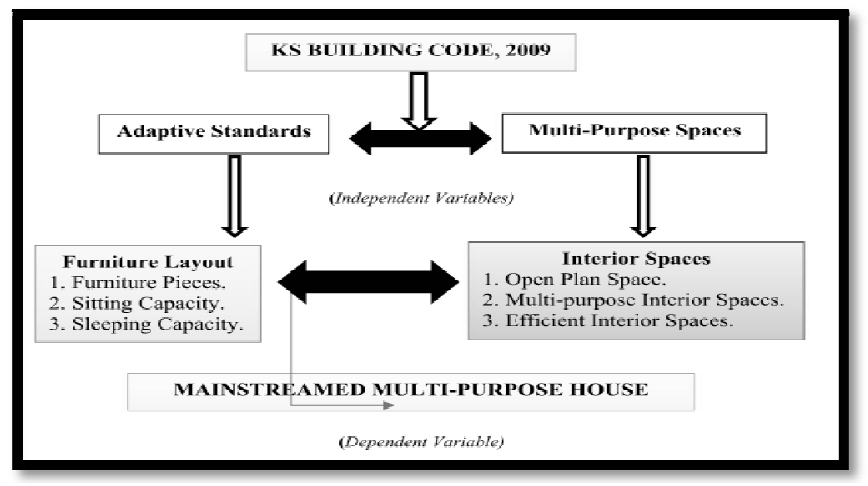

Figure 10: Conceptual Framework

Source: Author's Construct) 


\section{Methodology}

\subsection{Research Design}

Case study was the research design adopted by this study. Case studies are in-depth descriptions and analysis of a single unit or system, for example, individuals, events or groups held up by time and space (Hancock \& Algozzine, 2016). The case study model is applied since the researcher sought to investigate if at all the sizes of the interior spaces of the Kibera Soweto East Housing Project have attained the adaptive standards for multi-purpose room occupancy in low-cost housing projects in Kenya. Insights and results from this case study were then be used to recommend strategies for the total implementation of adaptive standards for the improvement of future slum upgrading housing programme.

\subsection{Population of the Study}

It mainly consists of the residents living in Soweto East, Zone A whose population is estimated to be around 5,900 (UN-HABITAT, 2008b). The seven professionals were also involved in the study included electrical engineers, architects, plumbers, contractors, mechanical engineers and quantity surveyors.

\subsection{Sampling Procedure}

Purposive sampling was used to identify professionals involved in the project who are seven in number. They included Architect Koech, Quantity Surveyor Busei, Engineer Mutalanga, Engineer Wambugu, Contractor Muthinga, Engineer Koech and Plumber Karago. Stratified random sampling design was used to come up with a proper representation of the residence of the Kibera Soweto East Housing Project who participated in the study. The population was grouped into 2 strata i.e. residents who live in the one bedroom houses which where 570 in number and two bedroom houses which were 144 in number. Simple random systematic sampling was then applied to each stratum. It was the preferred option since every resident had an opportunity of being sampled (Frankfort- Nachmias and Nachmias, 1996). The sampling unit was selected randomly using a table of random digits. 101 residents was the desired sample in this study with 81 residents interviewed from the one bedroom stratum and 20 residents interviewed from the two bedroom stratum Therefore drawing from 570 one bedroom houses and 144 two bedroom houses representing residents in the Kibera Soweto East Housing Project, (Mulcahy and Chu 2009), K=N/ $n$ where $\mathrm{K}$ stands for the sampling interval, $\mathrm{N}$ represents the population to be studied and $\mathrm{n}$ represents the desired population. As such for the one bedroom house; $\mathrm{K}=570 / 81, \mathrm{~K}=7$ and two bedroom house; $144 / 20, \mathrm{~K}=7$. Every 7 th house of each stratum was selected for inclusion in the sample. One resident was interviewed from each household. The sampling distribution can therefore be presented as indicated in Table 1 below;

\begin{tabular}{|c|c|c|c|}
\hline Size & Residents & Professionals & Total \\
\hline Population & 5,900 & 7 & 5,907 \\
\hline Sample & 101 & 7 & 108 \\
\hline
\end{tabular}

Table 1: Sample Frame (Source: Author's Construct, 2018)

\subsection{Data Collection Methods}

The qualitative data collection methods, in order of priority, undertaken in this study include examination of documents, interviews and observations. Each of them is illustrated in detail as follows;

\subsubsection{Examination of Documents}

In this study, critical analysis was done on existing resources such as government policies, guidelines and reports on The Kibera Soweto East Housing project and notes derived from them as well (Prior, 2003). Information in journals, conference proceedings, books and media publications on adaptive standards for multi-purpose interior design both in Kenya and worldwide were also looked at in detail and provision.

3.4.2. Interviews

In this study, semi-structured interviews were conducted so as to obtain first-hand information and reactions from the residents in regards to the size of their interior spaces. An interview is an outcome of an interaction between the interviewee and the researcher and it may be open, structured or semi-structured, dependent on the characteristics of structuring the interview by the researcher. Interviews are helpful to explore beliefs, occurrences, thoughts or views on particular issues. Reports can be explored and differentiated with others, to develop an appreciation of the fundamental structures of beliefs (Green \& Thorogood, 2010).

91 interviews were conducted right in front of their houses while 10 interviews were conducted inside their homes. 7 professionals were interviewed; 4 of them were conducted in their respective offices while the other 3 in different hotels in Nairobi, CBD. This then brings the total number of respondents interviewed to 108. This was indeed of great importance to the research as it helped the researcher understand what the real issues were and get suggestions directly from the residents on how to upgrade the interior spaces of these housing units meant for the low income earners. The professionals interviewed also helped understand how the low-cost housing project was conceptualized, implemented and the results thereof.

\subsubsection{Observations}

In this study, observations were made in 10 different houses. Observation is used to understand an occurrence by studying the actions and accounts of different people in an everyday context. It may be participant observation or nonparticipating observation such as using ethnography or video recordings where one participates, openly or covertly, in the 
daily lives of people for a long time period; listening to what is being said and watching what happens (Hammersley \& Atkinson, 2007). The various aspects that were observed during the research include furniture layouts, different activities/ functions carried out within a particular space, circulation and movement of people and human interaction with the different objects. Listening attentively to the residents as they went about their business was also important as it helped the researcher understand to what extend their appreciated their interior spaces.

\subsection{Data Analysis}

Qualitative analysis was employed during the study to analyze non-empirical data derived from in-depth interviews which were analyzed thematically. For each set of the data, a different code sheet was generated with an effort to determine and explain the relationships and patterns of the responses. This was done systematically so as to come up with meaningful recommendations and conclusions for the research undertaken (Mugenda and Mugenda 2003).

\subsection{Data Presentation} diagrams.

From the analysis; inferences and information obtained were presented in form of text, tables, bar graphs and

\subsection{Ethical Consideration}

The researcher was guided by the ethical issues as stated by Mugenda (2003), while carrying out this study. The research followed beneficence, justice as well as respect; which are the three principles of ethics. The respondents were notified beforehand of the purpose of the study thus conforming to the principle of informed consent and voluntary. Confidentiality, honesty and integrity were highly maintained throughout the study.

\subsection{Logical Framework}

\begin{tabular}{|c|c|c|c|c|c|}
\hline Objectives & Data Needs & $\begin{array}{c}\text { Data } \\
\text { Source } \\
\end{array}$ & $\begin{array}{c}\text { Data } \\
\text { Collection }\end{array}$ & $\begin{array}{l}\text { Analysis } \\
\text { Methods }\end{array}$ & Expected Output \\
\hline $\begin{array}{l}\text { 1. To establish the } \\
\text { adaptive standards } \\
\text { for multi-purpose } \\
\text { interior design in } \\
\text { Kenya. }\end{array}$ & $\begin{array}{l}\text { - } \\
\text { Documented } \\
\text { Information. }\end{array}$ & $\begin{array}{l}\text { - Journals, } \\
\text { conference } \\
\text { proceedings } \\
\text {, books, } \\
\text { media } \\
\text { publications } \\
\text { etc. }\end{array}$ & $\begin{array}{c}- \\
\text { Examination } \\
\text { of } \\
\text { Documents. }\end{array}$ & $\begin{array}{l}\text { Qualitativ } \\
\text { e Analysis. }\end{array}$ & $\begin{array}{l}\text { Information on the } \\
\text { adaptive } \\
\text { standards for } \\
\text { multi-purpose } \\
\text { interior design in } \\
\text { Kenya. }\end{array}$ \\
\hline $\begin{array}{l}\text { 2. To assess the } \\
\text { extent to which The } \\
\text { Kenya Slum } \\
\text { Upgrading } \\
\text { Programme } \\
\text { (KENSUP) has } \\
\text { applied the } \\
\text { adaptive standards } \\
\text { for multi-purpose } \\
\text { interior design in } \\
\text { Kenya. }\end{array}$ & $\begin{array}{c}\text { - } 101 \\
\text { Residents of } \\
\text { The Kibera } \\
\text { Soweto East } \\
\text { Housing } \\
\text { Project. } \\
\text { - } \\
\text { Documented } \\
\text { Information. }\end{array}$ & $\begin{array}{l}\text { - Filled } \\
\text { interview } \\
\text { guides. } \\
\text { - Notes on } \\
\text { observation } \\
\text { s made. } \\
\text { - Journals, } \\
\text { conference } \\
\text { proceedings } \\
\text {, books etc. }\end{array}$ & $\begin{array}{c}\text { - Interviews. } \\
- \\
\text { Observations } \\
\cdot \\
- \\
\text { Examination } \\
\text { of } \\
\text { Documents. }\end{array}$ & $\begin{array}{l}\text { Qualitativ } \\
\text { e Analysis. }\end{array}$ & $\begin{array}{l}\text { Knowledge on } \\
\text { how the Kenya } \\
\text { Slum Upgrading } \\
\text { Programme } \\
\text { (KENSUP) has } \\
\text { applied the } \\
\text { adaptive } \\
\text { standards for } \\
\text { multi-purpose } \\
\text { interior design in } \\
\text { Kenya. }\end{array}$ \\
\hline $\begin{array}{l}\text { 3. To recommend } \\
\text { strategies for the } \\
\text { total } \\
\text { implementation of } \\
\text { adaptive standards } \\
\text { for the } \\
\text { improvement of } \\
\text { future slums } \\
\text { upgrading housing } \\
\text { programmes. }\end{array}$ & $\begin{array}{c}\text { - } 101 \\
\text { Residents of } \\
\text { The Kibera } \\
\text { Soweto East } \\
\text { Housing } \\
\text { Project. } \\
-7 \\
\text { professional } \\
\text { s. } \\
\text { - } \\
\text { Documented } \\
\text { Information. }\end{array}$ & $\begin{array}{l}\text { - Filled } \\
\text { interview } \\
\text { guides. } \\
\text { - Notes on } \\
\text { observation } \\
\text { s made. } \\
\text { - Journals, } \\
\text { conference } \\
\text { proceedings } \\
\text {, books etc. }\end{array}$ & $\begin{array}{c}\text { - Interview } \\
\text { Guides. } \\
- \\
\text { Observation. } \\
- \\
\text { Examination } \\
\text { of } \\
\text { Documents. }\end{array}$ & $\begin{array}{l}\text { Qualitativ } \\
\text { e Analysis. }\end{array}$ & $\begin{array}{l}\text { A number of } \\
\text { strategies for the } \\
\text { total } \\
\text { implementation of } \\
\text { adaptive } \\
\text { standards for the } \\
\text { improvement of } \\
\text { future slums } \\
\text { upgrading housing } \\
\text { programmes. }\end{array}$ \\
\hline
\end{tabular}

Table 2: Logical Frame

Source: Author's Construct 


\section{Data Presentation and Analysis}

4.1. Gender of the Respondents

From the total number of people interviewed, $37 \%$ were male while $63 \%$ of them were female as shown in Table 3 and

\begin{tabular}{|c|c|c|}
\hline Gender & Frequency & Percentage (\%) \\
\hline Male & 40 & 37 \\
\hline Female & 68 & 63 \\
\hline Total & 108 & 100.0 \\
\hline
\end{tabular}

Table 3: Distribution of Respondents by Gender Author's Construct, 2018

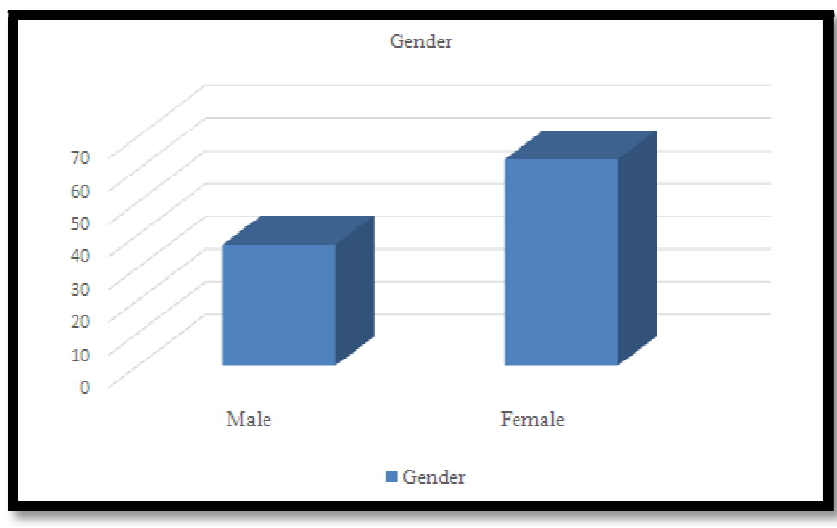

Figure 11: Distribution of Respondents by Gender Source: Author's Construct

4.2. Age Bracket of the Respondents

Majority of the residents (45.4\%) were between $34-44$ years of age. This was followed closely by those in the age bracket of 45 - 53 years of age comprised of $31.5 \%$ and 25 - 33 years of age comprising of $15.7 \%$ while those in the age bracket of between 54 - 64 years of age were $7.4 \%$ as indicated in Table 4 and Figure 13 respectively.

\begin{tabular}{|c|c|c|}
\hline Age (Years) & Frequency & Percentage (\%) \\
\hline $25-33$ & 17 & 15.7 \\
\hline $34-44$ & 49 & 45.4 \\
\hline $45-53$ & 34 & 31.5 \\
\hline $54-64$ & 8 & 7.4 \\
\hline Total & 108 & 100.0 \\
\hline
\end{tabular}

Table 4: Distribution Of Respondents By Age (Author's Construct, 2018)

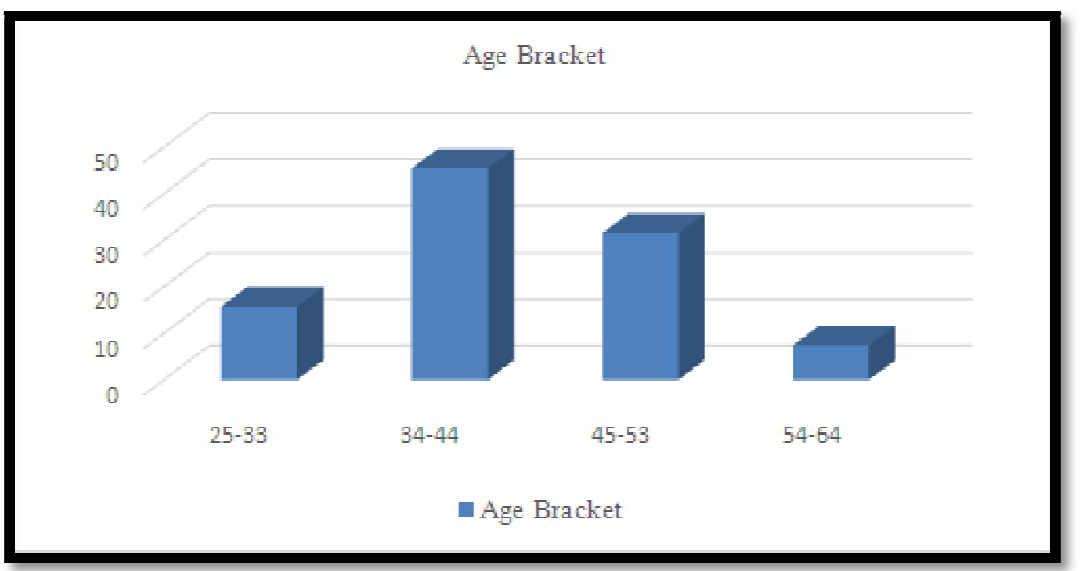

Figure 12: Distribution of Respondents by Age Source: Author's Construct 


\subsection{Respondents Responses on the Interior Spaces}

From the responses received from both the residents and professionals, $63.9 \%$ of them suggested for more open spaces especially between the living room and kitchen while $29.6 \%$ were okay with how the rooms were currently while $6.5 \%$ where not sure as shown in Table 5 and Figure 14 respectively.

\begin{tabular}{|l|l|l|}
\hline Responses & Frequency & Percentage (\%) \\
\hline More Open Spaces & 69 & 63.9 \\
\hline Current Rooms & 32 & 29.6 \\
\hline Not Sure & 7 & 6.5 \\
\hline Total & 108 & 100.0 \\
\hline
\end{tabular}

Table 5: Respondents Responses on More Open

Spaces (Author's Construct, 2018)

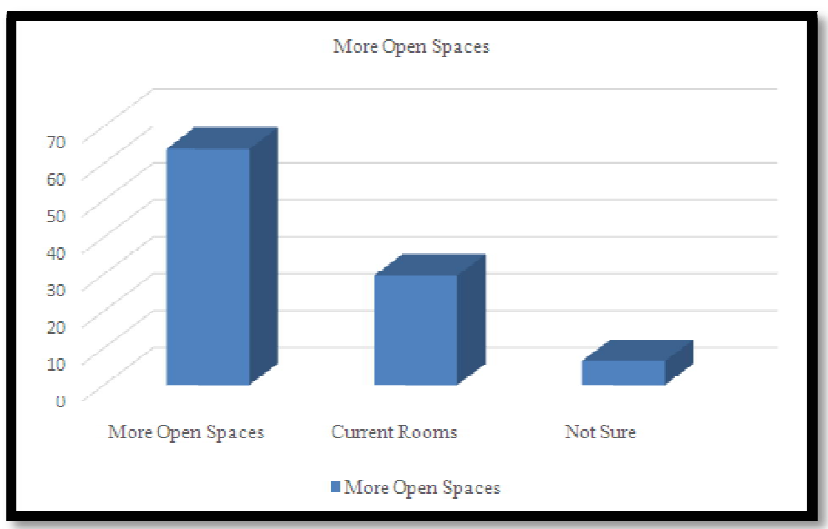

Figure 13: Respondents Responses on More Open Spaces (Author’s Construct, 2018)

\subsection{Multi-Purpose Spaces}

$52.8 \%$ of the respondents interviewed, preferred spaces that they could carry out more than one function in them. Taking the example of the bedroom, in addition to it being a place for sleeping children can study in them as well. In addition to the kitchen being a place where people prepare meals it can be a space where a family dines together. $35.2 \%$ preferred carrying out specific functions for which the different rooms are designated while $12.0 \%$ were sure about the idea of the spaces being multi-purpose or not as shown in Table 6 and Figure 15 respectively.

\begin{tabular}{|c|c|c|}
\hline Responses & Frequency & Percentage (\%) \\
\hline Multi-purpose Spaces & 57 & 52.8 \\
\hline Designated Spaces & 38 & 35.2 \\
\hline Not Sure & 13 & 12.0 \\
\hline Total & 108 & 100.0 \\
\hline
\end{tabular}

Table 6: Respondents Responses on Multi-Purpose Spaces (Author's Construct, 2018)

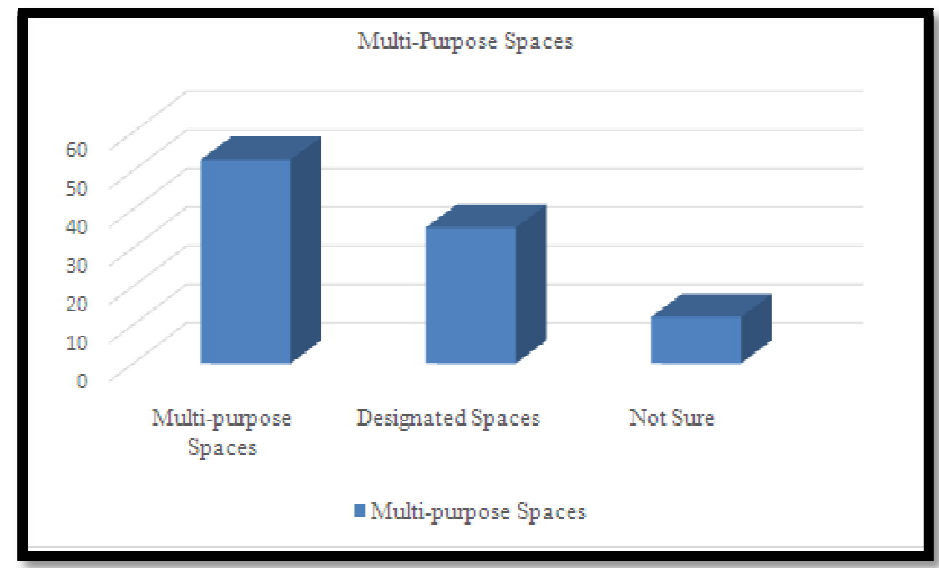

Figure 14: Respondents Responses on Multi - Purpose Spaces (Author's Construct, 2018)

\subsection{Functional Furniture Pieces}

Of the 101 residents of the Kibera Soweto East Housing Project interviewed, 71.3\% of them stated that they had furniture pieces in their spaces that were not functional, $16.8 \%$ were functional while $11.9 \%$ were not sure if they were functional or not as indicated in Table 7 and Figure 16. 


\begin{tabular}{|c|c|c|}
\hline Responses & Frequency & Percentage (\%) \\
\hline Functional & 72 & 71.3 \\
\hline Non-Functional & 17 & 16.8 \\
\hline Not Sure & 12 & 11.9 \\
\hline Total & 101 & 100.0 \\
\hline
\end{tabular}

Table 7: Respondents Responses on Functional Furniture

Pieces (Author's Construct, 2018)

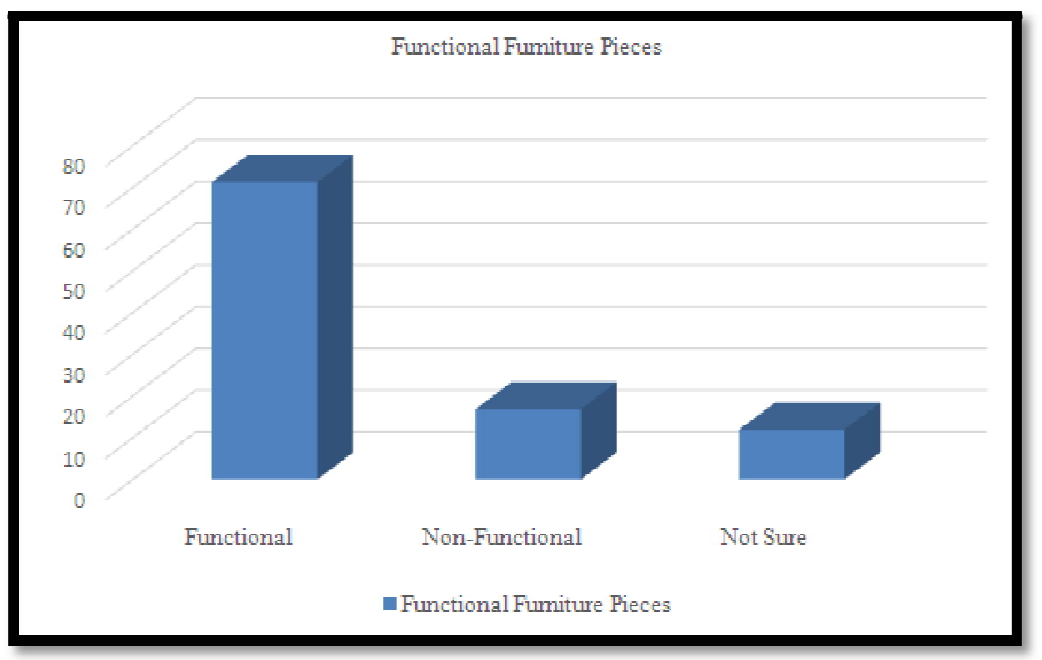

Figure 15: Respondents Responses on Functional Furniture Pieces Author's Construct, 2018

\subsection{Actual Space Sizes}

The one-bedroom house occupies an area of 38.44 sq. m. as illustrated in Figure17 while the two-bedroom house occupies an area of $69.16 \mathrm{sq}$. m. as illustrated in Figure18. Each room in the house is clearly distinct and separated from each other with floor to ceiling concrete wall of height $2400 \mathrm{~mm}$. The area of the living room for the one-bedroom house is $8.12 \mathrm{sq}$. $\mathrm{m}$. while that of the two-bedroom house is $9.30 \mathrm{sq}$. $\mathrm{m}$. The area of the bedroom for the one-bedroom house is 7.56 sq. $\mathrm{m}$. while that of the two-bedroom house is $8.40 \mathrm{sq}$. $\mathrm{m}$. The area of the kitchen for the one-bedroom house is $2.66 \mathrm{sq} . \mathrm{m}$. while that of the two-bedroom house is 2.94 sq. m. as shown in Figure 19 below.

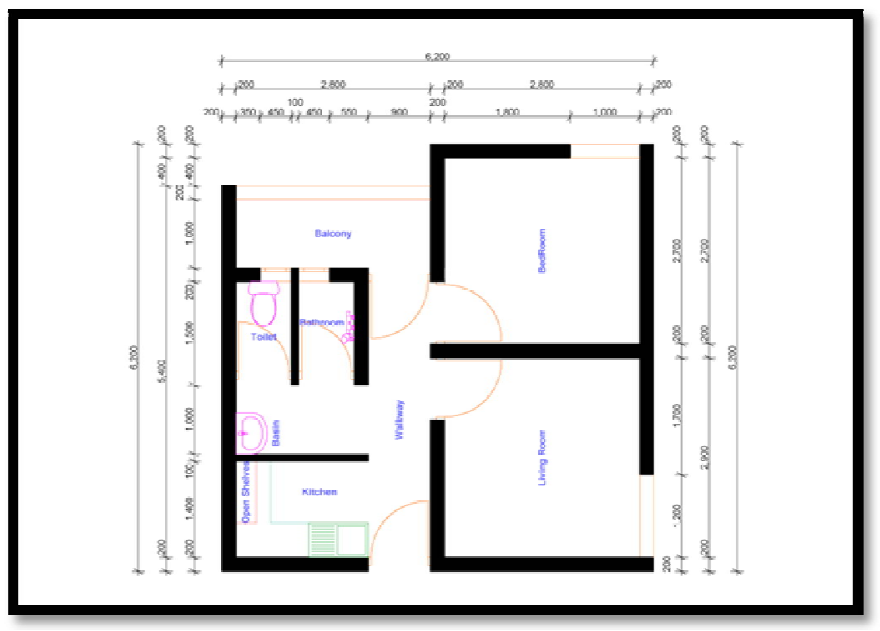

Figure 16: One Bedroom Floor Plan (Author's Construct, 2018)

The area for both the bathroom and toilet is $1.68 \mathrm{sq} . \mathrm{m}$. and the separation between these two rooms allows for people to use them at the same time. The area of the balcony for the one-bedroom house is $2.80 \mathrm{sq}$. $\mathrm{m}$. while that of the two-bedroom house is $1.40 \mathrm{sq}$. $\mathrm{m}$. The walkway distance for both the one bedroom and two-bedroom house is $900 \mathrm{~mm}$. The windows have a standard height and width of $1000 \mathrm{~mm}$ as well as a distance of $1000 \mathrm{~mm}$ from the floor. The doors have a height of $2100 \mathrm{~mm}$ and $900 \mathrm{~mm}$ in width. Sanitary ware is provided with a shower kit in the bathroom, a wash closet in the toilet and wash basin in the corridor. Tiles have been installed on the floor and walls of the bathroom as well as countertop for the kitchen. Countertops with inbuilt sink and dryer have been installed in the kitchen. Open wall mount cabinet has been provided in the kitchen as well so as to allow one to modify them in the best way that accommodates their lifestyle as illustrated in Figure 18 and 19 below. 


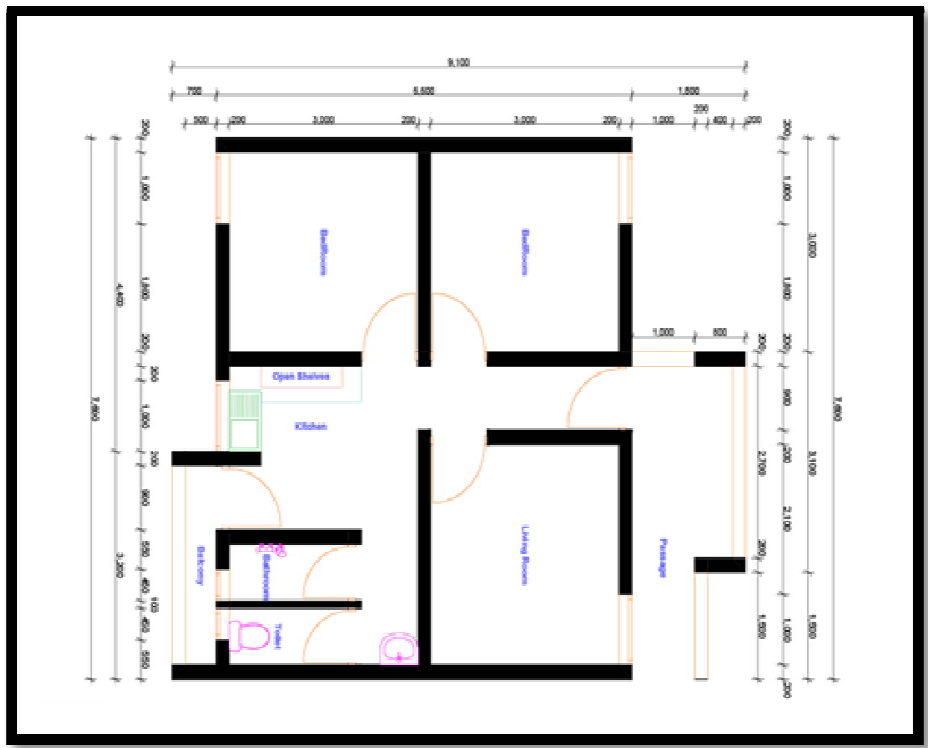

Figure 17: Two Bedroom Floor Plan (Author's Construct, 2018)

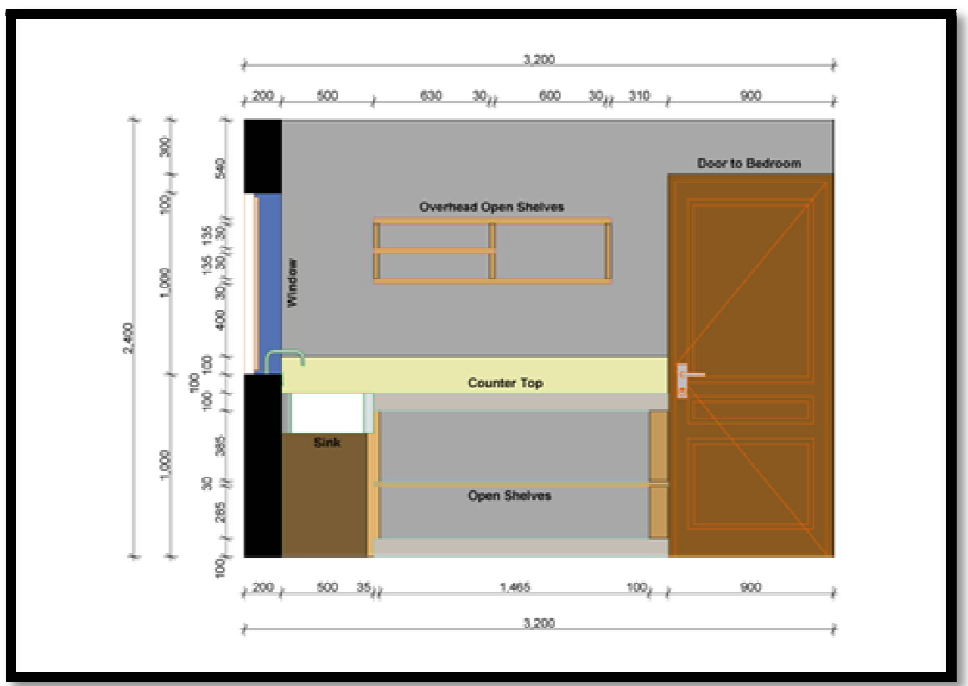

Figure 18: Kitchen Shelving Particulars (Author's Construct, 2018)

4.7. Spatial Analysis on Living Room Spaces

Ten houses were analyzed; three of them are illustrated in Figure 20, 21 and 22.

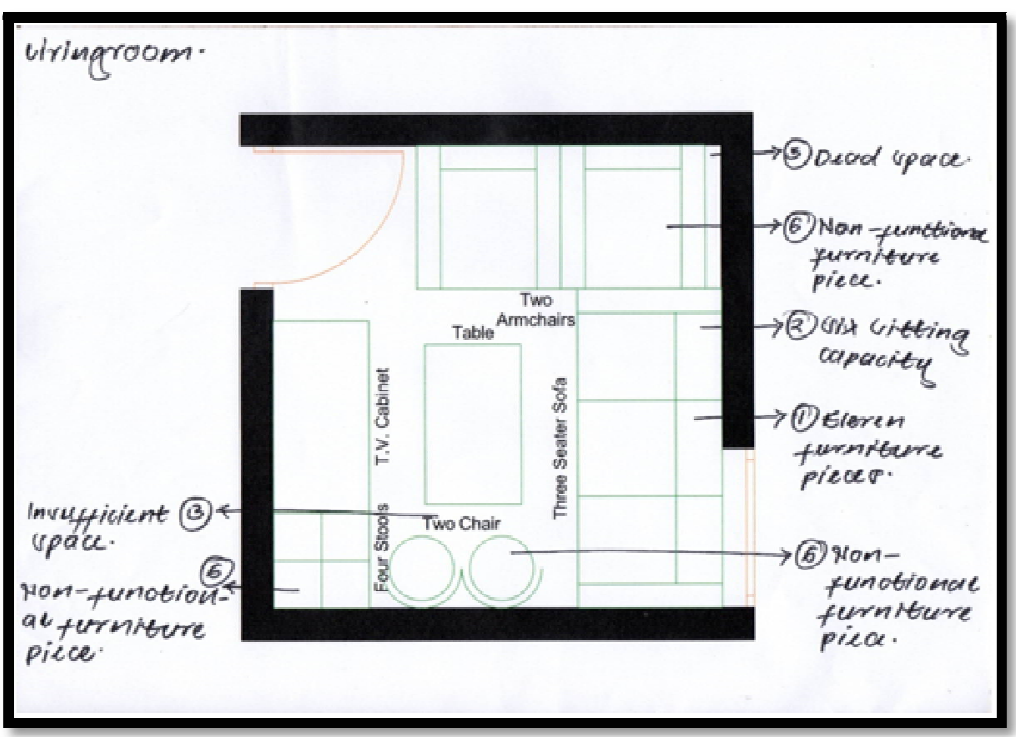

Figure 19: Living Room, Floor Plan One (Author's Construct, 2018) 


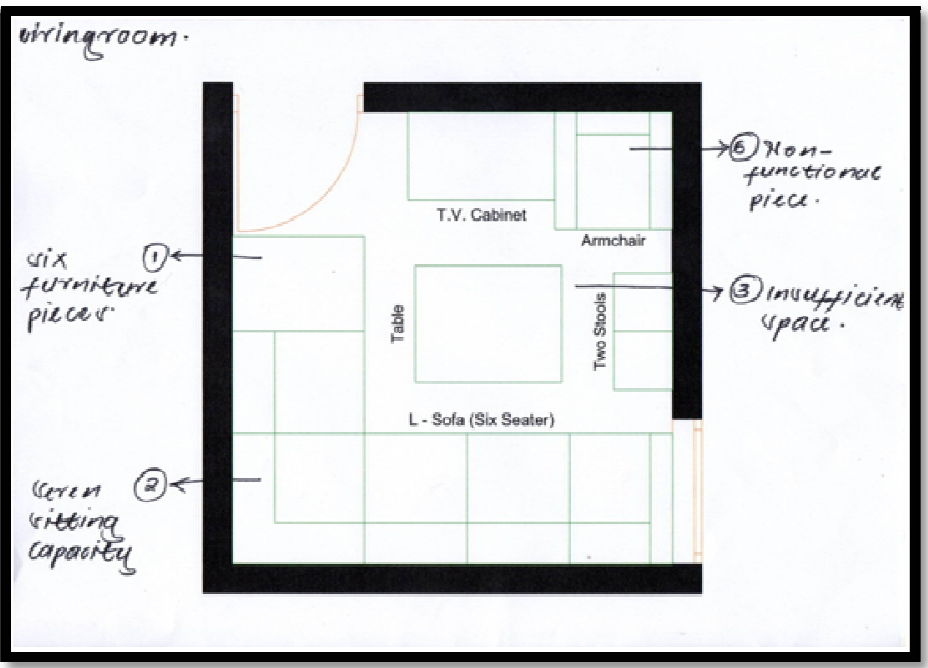

Figure 20: Living room, Floor Plan Two (Author's Construct, 2018).

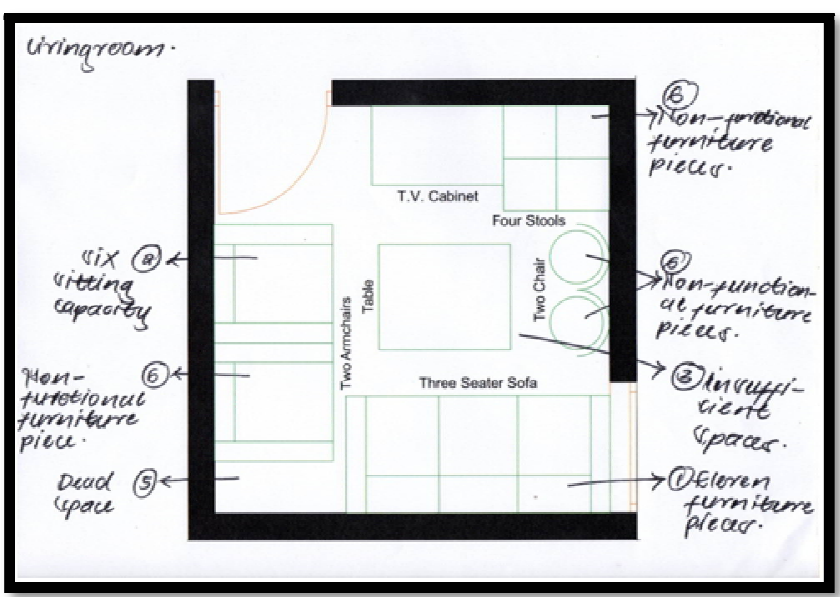

Figure 21: Living Room, Floor Plan Three (author's construct, 2018)

4.8. Non-Functional Furniture Pieces in Living Rooms

Out of the ten analyzed houses, $80 \%$ had furniture pieces that were either partly or fully non-functional while $20 \%$ of them had all their furniture pieces fully functional as shown in Table 8 and Figure 23 respectively.

\begin{tabular}{|l|l|l|}
\hline Responses & Frequency & Percentage (\%) ) \\
\hline Non- Functional Furniture Pieces & 8 & 80 \\
\hline Functional Furniture Pieces & 2 & 20 \\
\hline Total & 10 & 100 \\
\hline
\end{tabular}

Table 8: Analysis on Non-Functional Furniture Pieces in Living Rooms (Author's Construct, 2018)

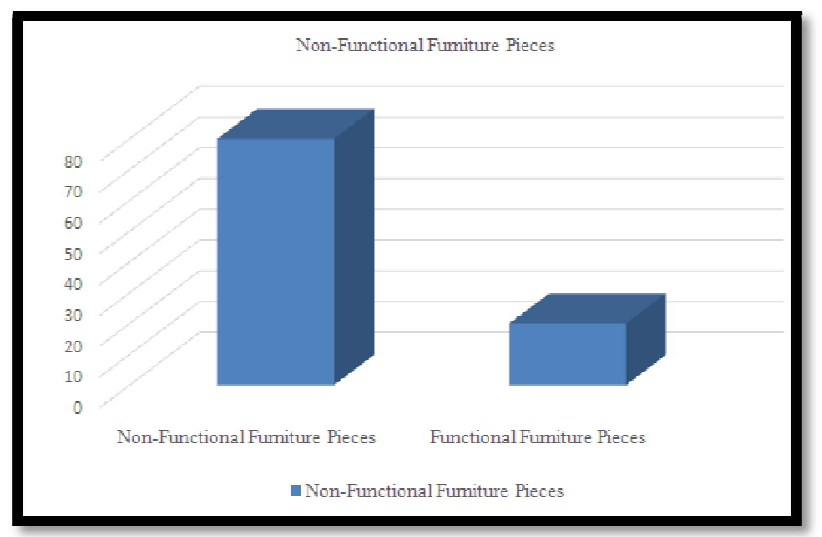

Figure 22: Analysis on Non-Functional Furniture Pieces in Living Rooms (Author's Construct, 2018) 


\subsection{Dead Space in Living Rooms}

Out of the ten analyzed houses, $50 \%$ had dead spaces while $50 \%$ had all the spaces inside the room fully utilized as demonstrated in Table 9 and Figure 24 respectively.

\begin{tabular}{|c|c|c|}
\hline Responses & Frequency & Percentage (\%) \\
\hline Dead Spaces & 5 & 50 \\
\hline Fully Utilized Spaces & 5 & 50 \\
\hline Total & 10 & 100 \\
\hline
\end{tabular}

Table 9: Analysis on Dead Spaces in Living

Rooms (Author's Construct, 2018)

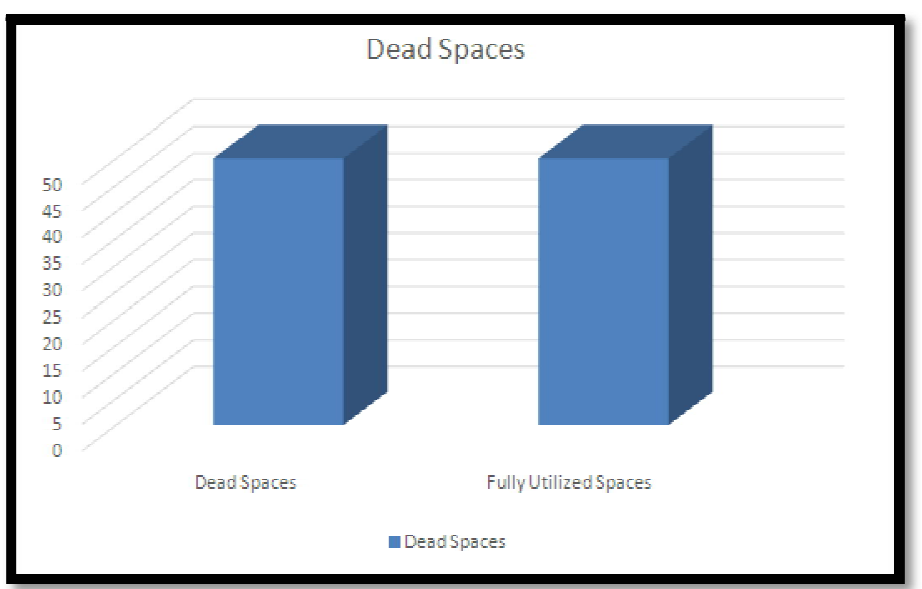

Figure 23: Analysis on Dead Spaces in Living

Rooms (Author's Construct, 2018)

\subsection{Insufficient Space in Living Rooms}

Out of the ten analyzed houses, $60 \%$ had insufficient spaces while $40 \%$ had sufficient spaces as demonstrated in Table 10 and Figure 25 respectively.

\begin{tabular}{|c|c|c|}
\hline Responses & Frequency & Percentage (\%) \\
\hline Insufficient Spaces & 6 & 60 \\
\hline Sufficient Spaces & 4 & 40 \\
\hline Total & 10 & 100 \\
\hline
\end{tabular}

Table 10: Analysis on Insufficient Spaces in Living Rooms (Author's Construct, 2018)

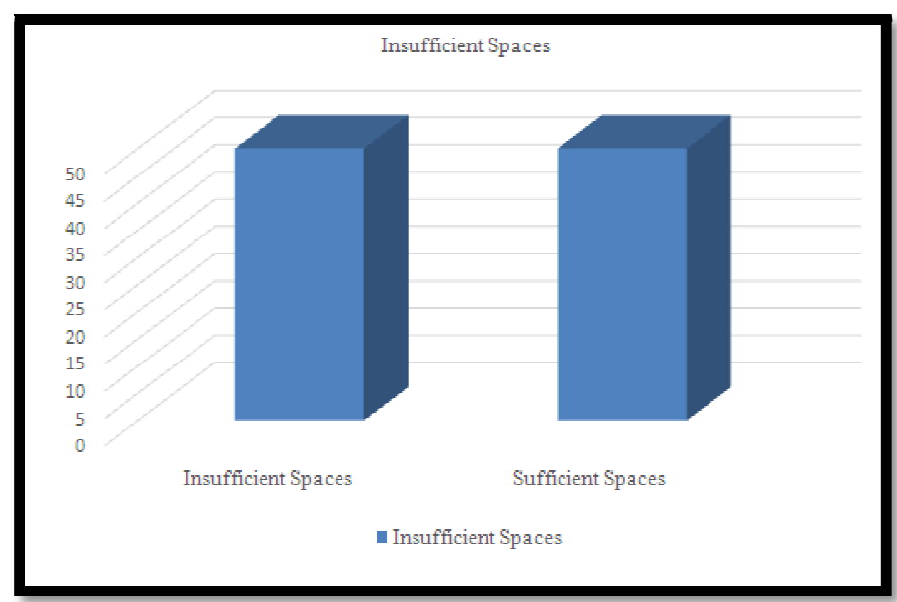

Figure 24: Analysis on Insufficient Spaces in Living Rooms (Author's Construct, 2018)

\subsection{Spatial Analysis on Bedroom Spaces}

Ten houses were analyzed, three of them are illustrated in Figure 26, 27 and 28. 


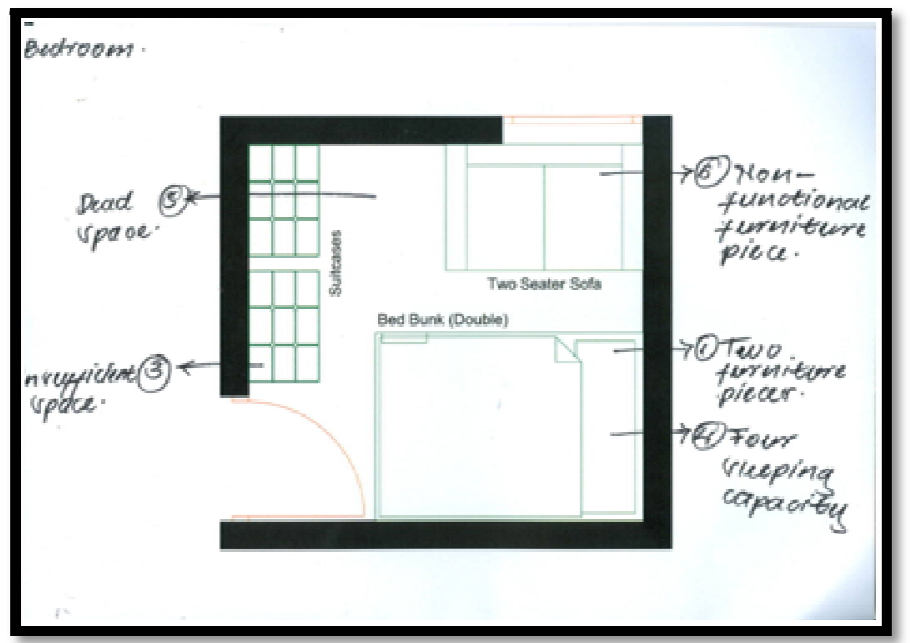

Figure 25: Bedroom, Floor Plan One (Author's Construct, 2018)

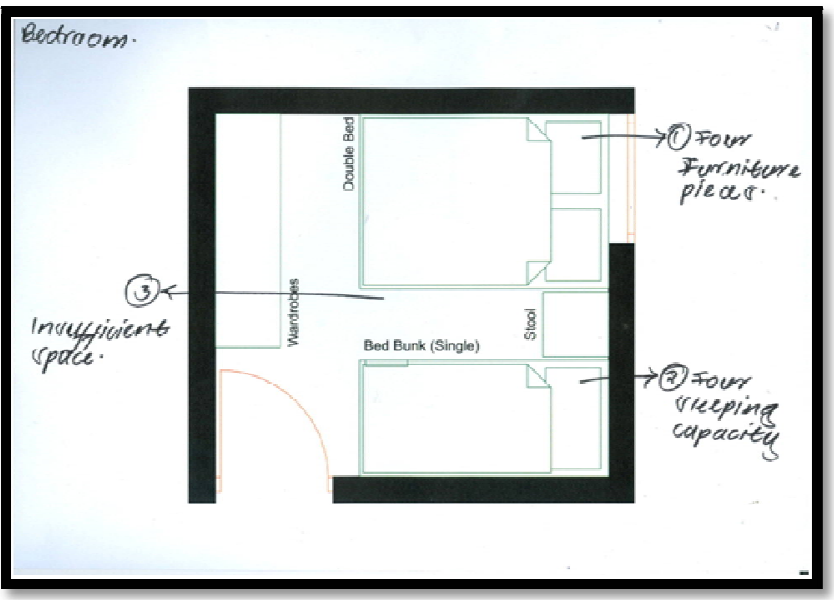

Figure 26: Bedroom, Floor Plan Two (Author's Construct, 2018)

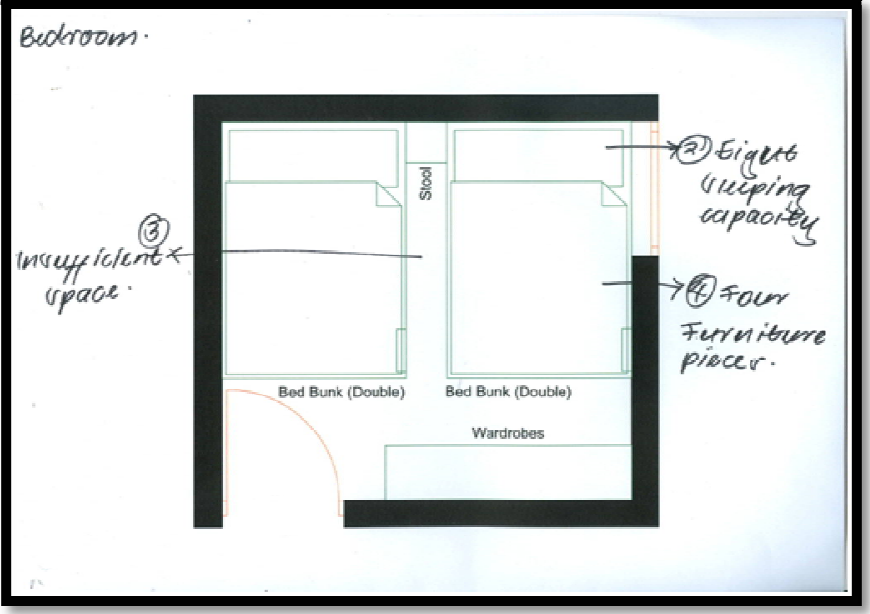

Figure 27: Bedroom, Floor Plan Three (Author's Construct, 2018)

\subsection{Insufficient Spaces in Bedrooms}

Out of the ten analyzed houses, $80 \%$ had insufficient spaces while $20 \%$ of them had sufficient spaces as shown in Table 11 and Figure 29 respectively.

\begin{tabular}{|c|c|c|}
\hline Responses & Frequency & Percentage (\%) \\
\hline Insufficient Spaces & 8 & 80 \\
\hline Sufficient Spaces & 2 & 20 \\
\hline Total & 10 & 100 \\
\hline
\end{tabular}

Table 11: Analysis on Insufficient Spaces in Bedrooms (Author's Construct, 2018) 


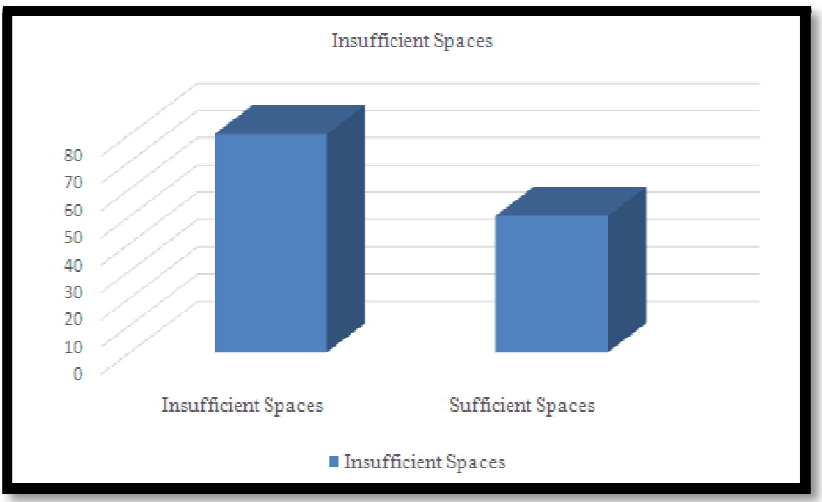

Figure 28: Analysis on Insufficient Spaces in Bedrooms Author's Construct, 2018

\section{Findings and Discussions}

\subsection{Findings on the Individual Interior Spaces}

As prescribed in the KS Building Code, 2009, the overall plan area for any multi-purpose room in low cost housing shall be not less than 10.50 sq. m. As for the Kibera Soweto East Housing Project, the area of the living room for the onebedroom house is $8.12 \mathrm{sq}$. $\mathrm{m}$. while that for two-bedroom house is $9.30 \mathrm{sq}$. $\mathrm{m}$. This does falls short of the recommended adaptive standards by 2.38 sq. $\mathrm{m}$. for the one-bedroom house and $1.20 \mathrm{sq}$. $\mathrm{m}$. for the two-bedroom house. This affects the living standards in that, in an ideal setting, the living room of the one-bedroom house can only accommodate two furniture layouts while that of the two-bedroom house can only accommodate three furniture layouts while maximizing on space. One furniture layout for the one-bedroom living room can only accommodate seven furniture pieces and a sitting capacity of five people while the other layout can only accommodate nine furniture pieces and a sitting capacity of four people. This is indicated in Figures 30 and 31 respectively.

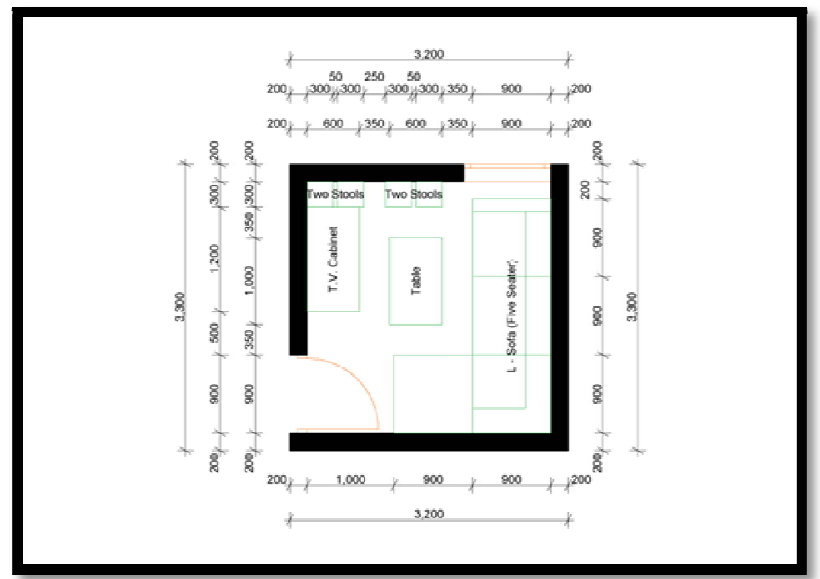

Figure 29: One Bedroom, Living Room, and Furniture Layout One (Author's Construct, 2018)

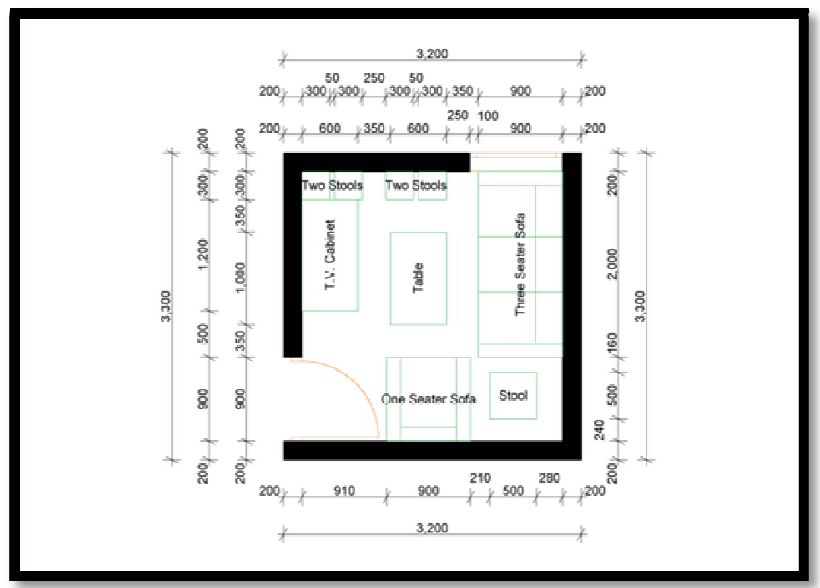

Figure 30: One Bedroom, Living Room, Furniture Layout Two Author's Construct, 2018 
As for the two-bedroom house, the living room can only accommodate three furniture layouts. The first layout accommodating three significant furniture pieces and a sitting capacity of six people, the second layout accommodating three significant furniture pieces and a sitting capacity of five people while the third accommodating three significant furniture pieces and a sitting capacity of five people; all illustrated in Figures 32, 33 and 34 respectively in the following pages.

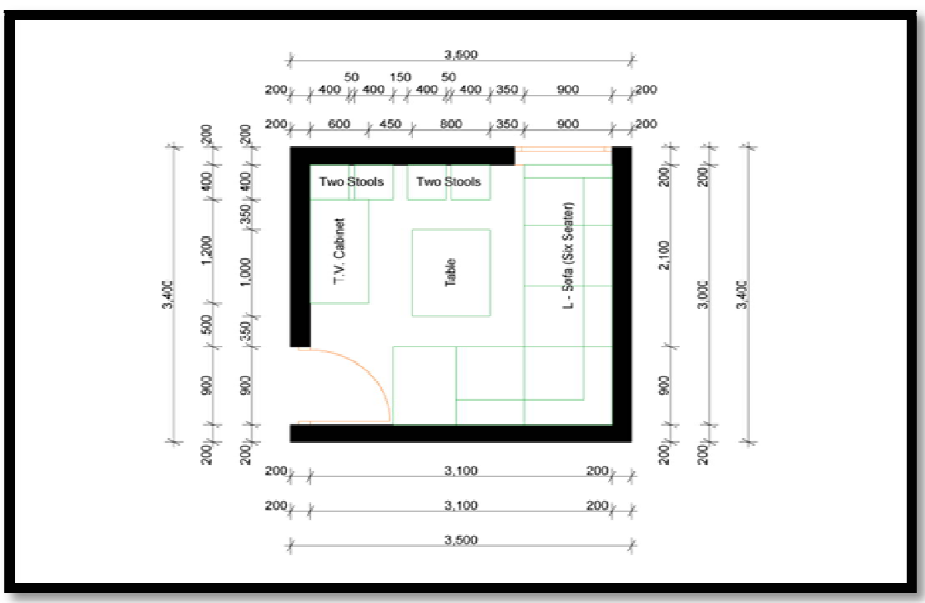

Figure 31: Two Bedrooms, Living Room, Furniture Layout One Author's Construct, 2018

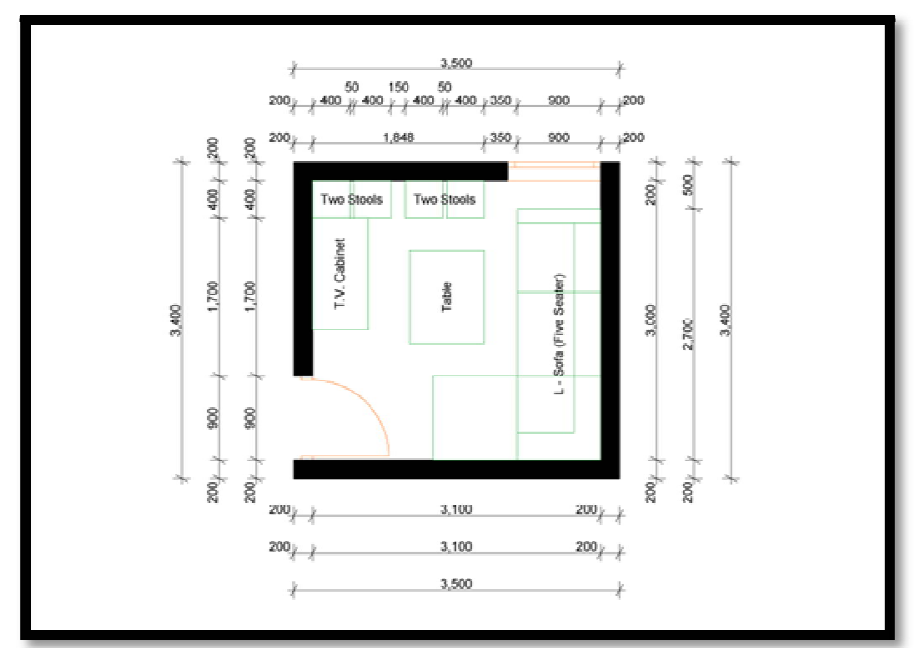

Figure 32: Two Bedroom, Living Room, Furniture Layout Two Author's Construct, 2018

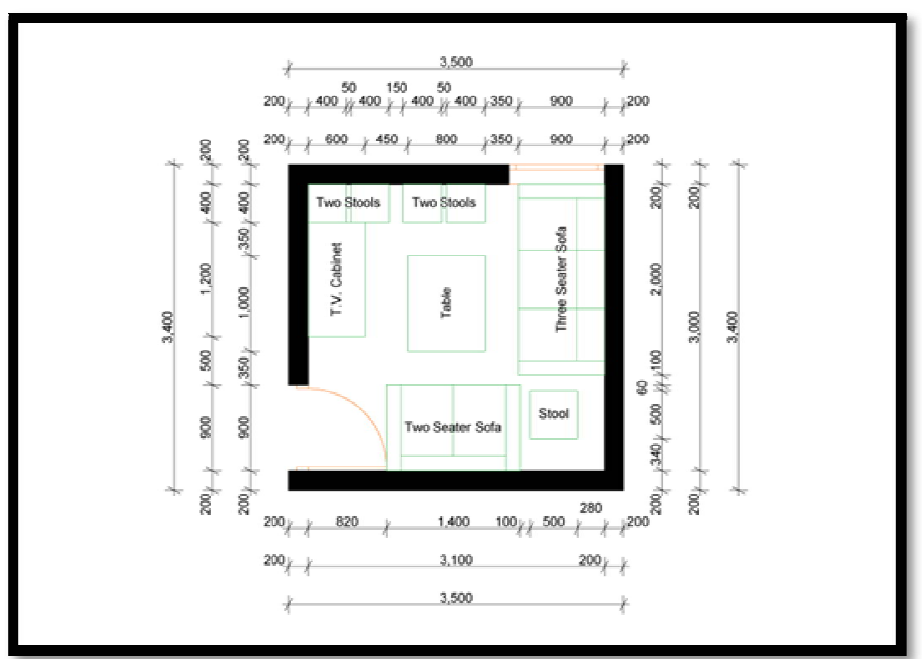

Figure 33: Two Bedroom, Living Room, Furniture Layout Three Author's Construct, 2018 


\subsection{Bedroom}

The recommended adaptive standard overall plan area of not less than 10.50 sq. m. as stated in the KS Building Code, 2009 still applies in this case. The area for the one-bedroom house is $7.56 \mathrm{sq} . \mathrm{m}$. while that for two-bedroom house is 8.40 sq. $\mathrm{m}$. This does falls short of the recommended standards by $2.94 \mathrm{sq}$. $\mathrm{m}$. for the one-bedroom house and $2.10 \mathrm{sq} . \mathrm{m}$. for the two-bedroom house. This also does affects the living standards in that, in an ideal setting, the bedroom for the onebedroom house has only one furniture layout that accommodates three significant furniture pieces and a sleeping capacity of five people as illustrated in image 35 while that of the two-bedroom house, have only two furniture layouts. The first one accommodating three significant furniture pieces and a sleeping capacity of four people while the second layout accommodates three significant furniture pieces and a sleeping capacity of six people as illustrated in Figures 36 and 37 respectively.

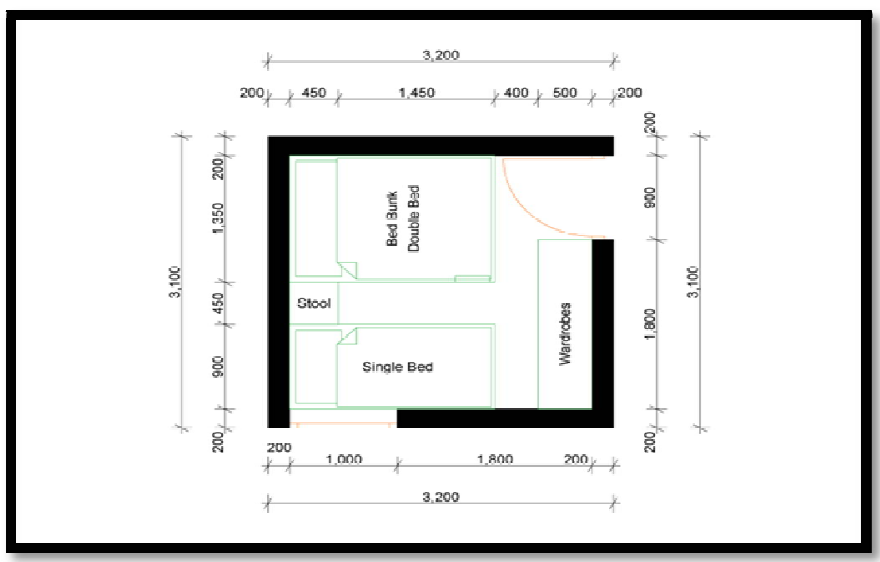

Figure 34: One Bedroom, Bedroom, and Furniture Layout Author's Construct, 2018

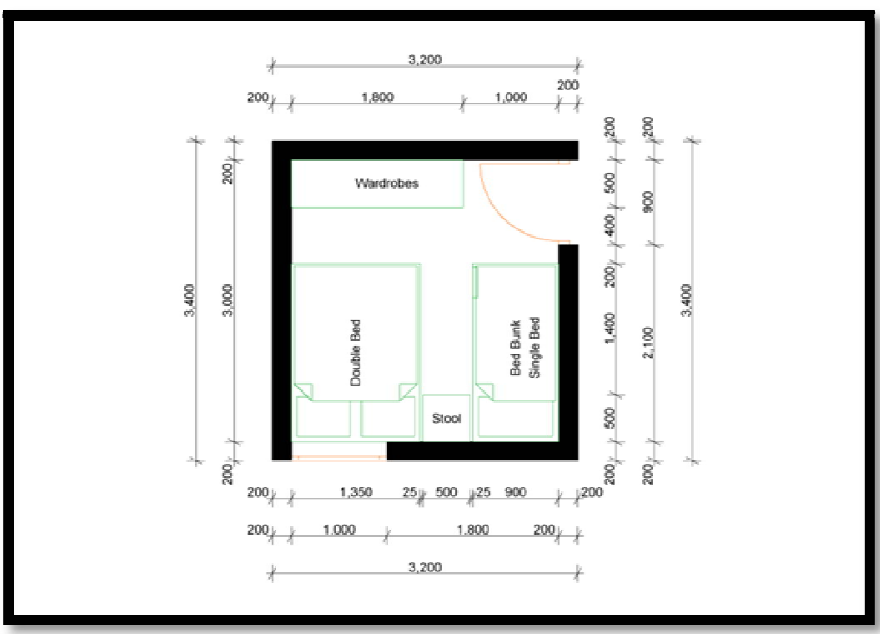

Figure 35: Two Bedroom, Bedroom, Furniture Layout One (Author's Construct, 2018)

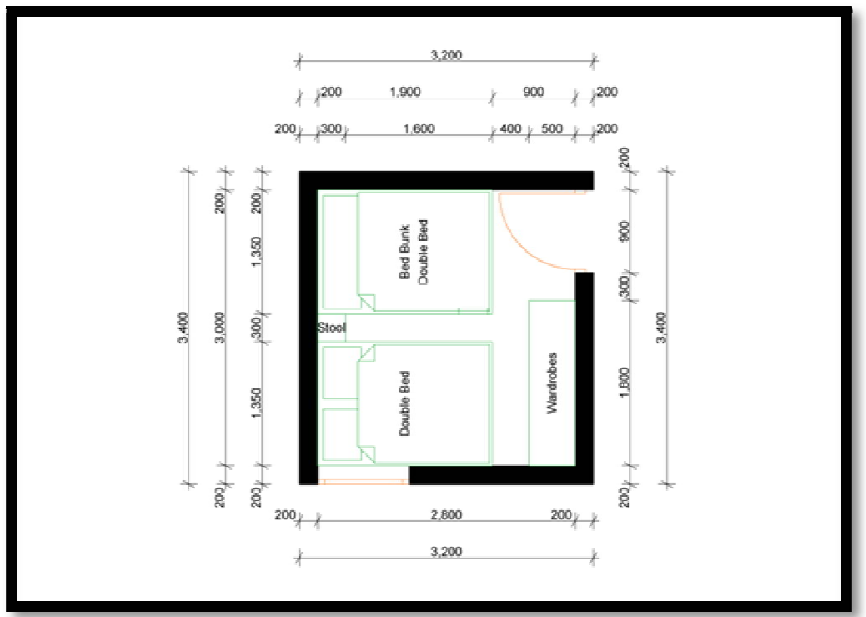

Figure 36: Two Bedroom, Bedroom, Furniture Layout Two Author's Construct, 2018 


\subsection{Kitchen}

The KS Building Code, 2009 outlines that akitchen shall be provided for every dwelling of two or more habitable rooms, that is not less than 3.30 sq. m. in area size for plots up to 50 sq. m. and $4.50 \mathrm{sq}$. m. for plots above 50 sq. m. with the minimum horizontal dimension of which shall be $1.82 \mathrm{~m}$. In the case of the Kibera Soweto East Housing Project, the one-bedroom house falls under the category of those plots which are up to 50 sq. m. since it occupies an area of 38.44 sq. $\mathrm{m}$. while the two-bedroom house falls under the category of those plots which are above $50 \mathrm{sq} . \mathrm{m}$. since it occupies an area of $69.16 \mathrm{sq} . \mathrm{m}$. The area of the kitchen for the one-bedroom house is $2.66 \mathrm{sq} . \mathrm{m}$. while that of the two-bedroom house is 2.94 sq. m. This does falls short of the recommended standards by 0.64 sq. m. for the one-bedroom house and 1.56 sq. $\mathrm{m}$. for the two-bedroom house.

\subsection{Bathroom}

In the case of the bathroom, the KS Building Code, 2009 states that the minimum requirement for bathrooms in plots that are 50 sq. $\mathrm{m}$. and below is 1.20 sq. m. while that which are above 50 sq. m. is 1.80 sq. $\mathrm{m}$. The one bedroom for the Kibera Soweto East Housing falls under the category of those plots which are up to 50 sq. m. since it occupies an area of 38.44 sq. $\mathrm{m}$. while the two-bedroom house falls under the category of those plots which are above $50 \mathrm{sq} . \mathrm{m}$. since it occupies an area of $69.16 \mathrm{sq}$. $\mathrm{m}$. The area of the bathroom for both the one bedroom and two-bedroom house is $1.68 \mathrm{sq} . \mathrm{m}$. This does falls short of the recommended standards by $0.12 \mathrm{sq}$. $\mathrm{m}$. for the two-bedroom house.

\section{Conclusions and Recommendations}

\subsection{Summary of the Findings}

The first research objective of the study sought to establish the adaptive standards for multi-purpose interior design in Kenya. The KS Building Code, 2009, prescribes the following recommendations for the construction of housing projects meant for the low-income earners like The Kibera Soweto East Housing Project: -

- The overall plan area for any multi-purpose room i.e. living room and bedroom shall be not less than 10.50 sq. m.

- A kitchen shall be provided for every dwelling of two or more habitable rooms, that is not less than $3.30 \mathrm{sq}$. $\mathrm{m}$. in area size for plots up to $50 \mathrm{sq}$. $\mathrm{m}$. and $4.50 \mathrm{sq}$. $\mathrm{m}$. for plots above $50 \mathrm{sq}$. m. with the minimum horizontal dimension of which shall be $1.82 \mathrm{~m}$.

- The minimum requirement for bathrooms in plots that are 50 sq. m. and below is 1.20 sq. m. while that which are above 50 sq. $\mathrm{m}$. is 1.80 sq. $\mathrm{m}$.

The second research objective was geared towards assess the extent to which the Kenya Slum Upgrading Programme (KENSUP) has applied the adaptive standards for multi-purpose interior design in Kenya. In the case of the one-bedroom house; the living room of $8.12 \mathrm{sq}$. $\mathrm{m}$. fell short by $2.38 \mathrm{sq}$. $\mathrm{m}$.; the bedroom of $7.56 \mathrm{sq}$. m. fell short by $2.94 \mathrm{sq}$. $\mathrm{m}$. and the kitchen of $2.66 \mathrm{sq}$. $\mathrm{m}$. fell short by 0.64 . For the two-bedroom house; the living room of $9.30 \mathrm{sq}$. $\mathrm{m}$. fell short by 1.20 sq. $\mathrm{m}$.; the bedroom of 8.40 sq. $\mathrm{m}$. fell short by 2.10 sq. m.; the kitchen of 2.94 sq. m. fell short by 1.56 sq. m. and the bathroom of $1.68 \mathrm{sq}$. $\mathrm{m}$. fell short by $0.12 \mathrm{sq}$. $\mathrm{m}$. This is according to the prescribed standards stated in the KS Building Code, 2009.

The third research objective was to recommend strategies for the total implementation of adaptive standards for the improvement of future slum upgrading housing programmes. They include: -

- Employing the open plan concept by combining the living room and kitchen into one big space. The kitchen counter top can then be used as a partial divider between the two spaces.

- Elimination of corridors to create more space for other rooms.

- Installation of sliding doors instead of hinged doors.

\subsection{Conclusions}

One of the ways that the government is using to elevate the poor in the slum areas is though the construction of housing units meant for the low-income earners through various initiatives such as the Kenya Slum Upgrading Program (KENSUP). However, during construction a lot of focus is placed on constructing these houses with the least amount of materials and ensure that the project takes up the least of the finances. With these in mind, they end up creating small spaces that are not up to standard as prescribed in the KS Building code, 2009. The area sizes of the specific spaces are therefore reduced significantly which then limits the number of furniture layouts, furniture pieces, sitting and sleeping capacity as well as the number of tasks and functions that can be carried out within a particular space. This then beats the sole reason why the code was put in place which is to provide adequate, affordable, sustainable, well planned, safe, healthy, decent and quality low cost housing. This then does negatively affects the living standards and quality of life of residents.

\subsection{Recommendations}

From the research conducted, there's clear evidence that most of the standard area sizes for specific rooms in lowcost housing as prescribed in KS Building Code 2009, have not been adhered too. However, the adaptive standards for multi-purpose interior design in low-cost housing projects in Kenya can be attained through a number of interior modifications that necessary do not interfere with the exterior structure of the building.

One would be to employ the open plan concept by combining the living room and kitchen into one big space as shown in image 38, 39, 40 and 41. The kitchen counter top would then be used as a partial divider between the two spaces. One of the factors that necessitated the coming up with the space standard sizes under the code was to give room for innovate 
design concepts to come up. The open plan space concept is indeed one of them as it enables the room areas to attain the set sizes. This concept allows for different furniture layouts which brings about well-planned spaces as well as performers of different tasks and functions within a particular space which also enhances performance and functionality; factors which contributed to coming up with the standards under code.

Elimination of corridors to create more space for other rooms as indicated in image 38, 39, 40 and 41 .The entrance door would be moved to the living room and the doors to the bedroom would share the same wall as that of the living room and kitchen. The space created would then be distributed to the other rooms hence creating more space. This would increase the distance between two furniture pieces hence easing circulation and therefore create safe interior space. It would also bring about the accommodation of a variety of furniture layouts and interior space configuration which results to well-planned interior spaces. It allows residents as well to modify their interior spaces since their lifestyle, needs and wants tend to change rapidly over time.

Installation of sliding doors instead of hinged doors as indicated in image 38, 39, 40 and 41.The extra space created can then be used for more storage and other functions to take place. The interior spaces would as well accommodate more or larger pieces of furniture which would then accommodate better or a greater number of family members. These would raise the living standards in that most people in the slums have large families.

With these changes in effect, the living room's area for the one-bedroom house would increase from 8.12 sq. m. to 11.31 sq. $m$. which is higher than the prescribed overall plan area for any multi-purpose room by the KS Building Code, 2009 which is 10.50 sq. $\mathrm{m}$. This would result to the sitting capacity increasing from a five to an eight seater space while the number of furniture pieces to be incorporated would increase from seven to eightas indicated in image 38.The living room's area for the two-bedroom house would increase from 9.30 sq. m. to 12.9 sq. m. which is higher than 10.50 sq. m. This would result to the sitting capacity increasing from a six to a nine seater space while the number of significant furniture pieces to be incorporated would increase from three to eight. The number of furniture layouts would increase from three to four as indicated in Figures 39, 40 and 41.

For the two-bedroom house, the area of the bedroom would increase from $8.40 \mathrm{sq} . \mathrm{m}$. to the highest square meter being $12.60 \mathrm{sq}$. $\mathrm{m}$. which is greatest than $10.5 \mathrm{sq} . \mathrm{m}$. as illustrated in image 41 . This would result to the sleeping capacity space increasing from six to a nine while the number of furniture pieces to be incorporated would increase from four to six. The number of furniture layouts that residents can work with would increase from three to four as indicated in Figures39, 40 and 41.

The kitchen area for the one-bedroom house would increase from 2.66 sq. m. to 3.42 sq. m. which is higher than 3.30 sq. $\mathrm{m}$. for plots up to 50 sq. $\mathrm{m}$. as indicated in image 38. For the two-bedroom house it would increase from $2.94 \mathrm{sq} . \mathrm{m}$. to 5.40 sq. m. which is higher than 4.50 sq. m. for plots above 50 sq. m. as shown in Figure 39, 40 and 41 .The bathroom area for the two-bedroom house would be1.84 sq. $\mathrm{m}$ from $1.68 \mathrm{sq} . \mathrm{m}$. which is higher than the recommended area of 1.80 sq. m. as indicated in Figures 39, 40 and 41 below.

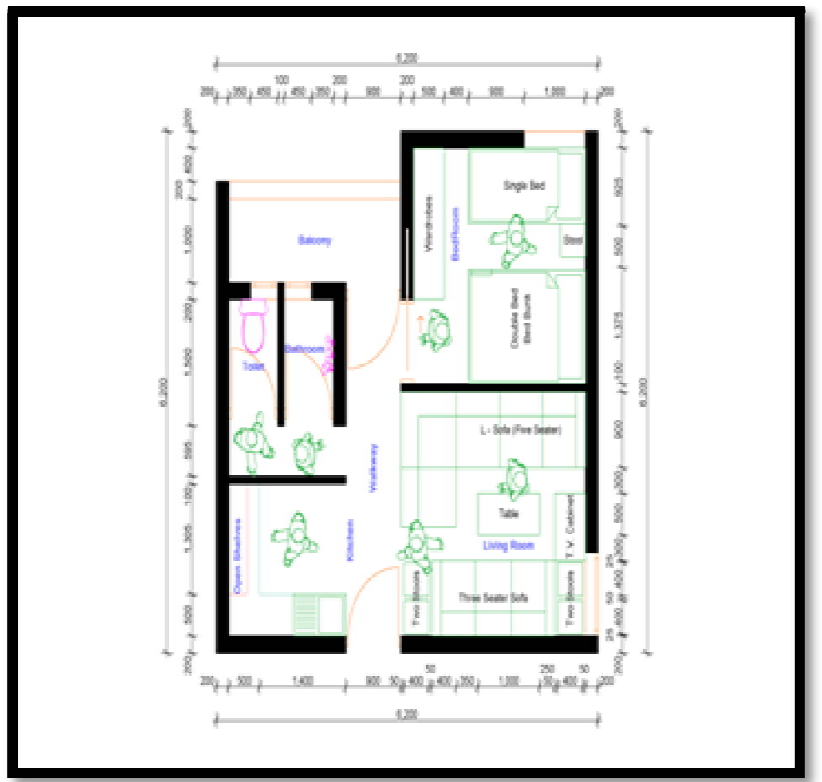

Figure 37: One Bedroom House Floor Layout Plan Author's Construct, 2018 


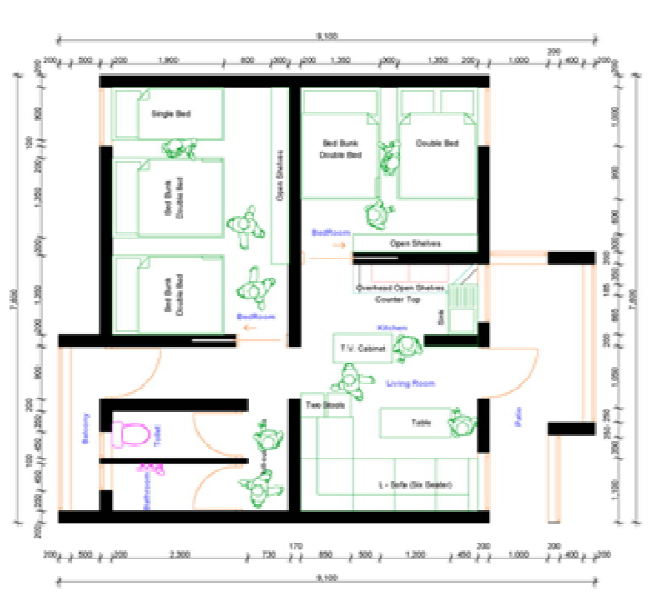

Figure 38: Two Bedroom House Floor Layout Plan Option One Author's Construct, 2018

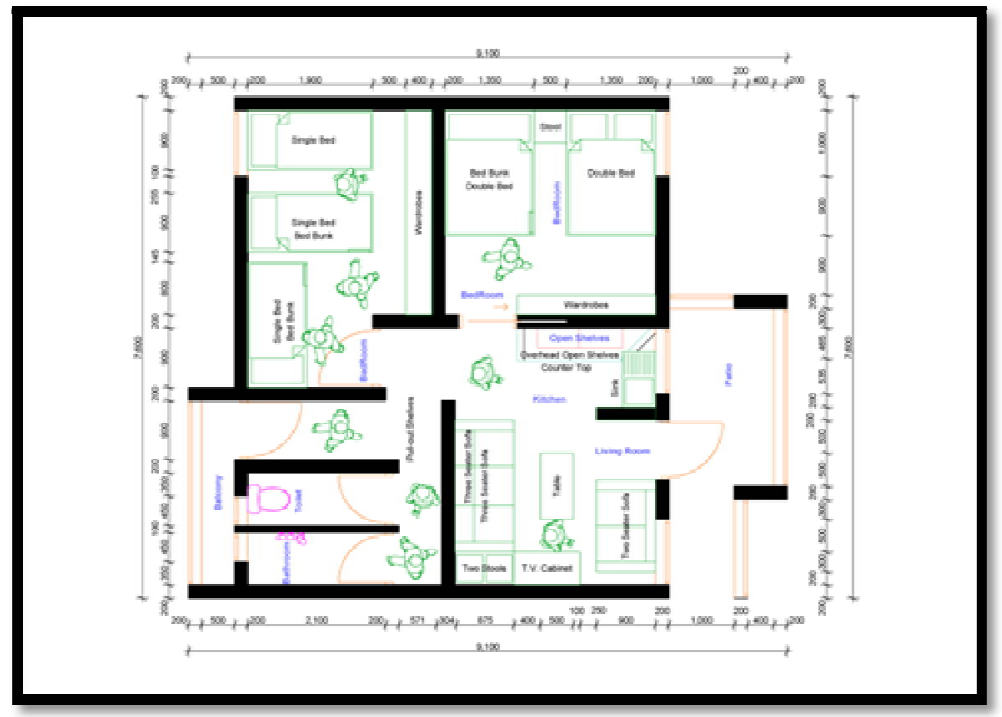

Figure 39: Two Bedroom House Floor Layout Plan Option Two Author's Construct, 2018

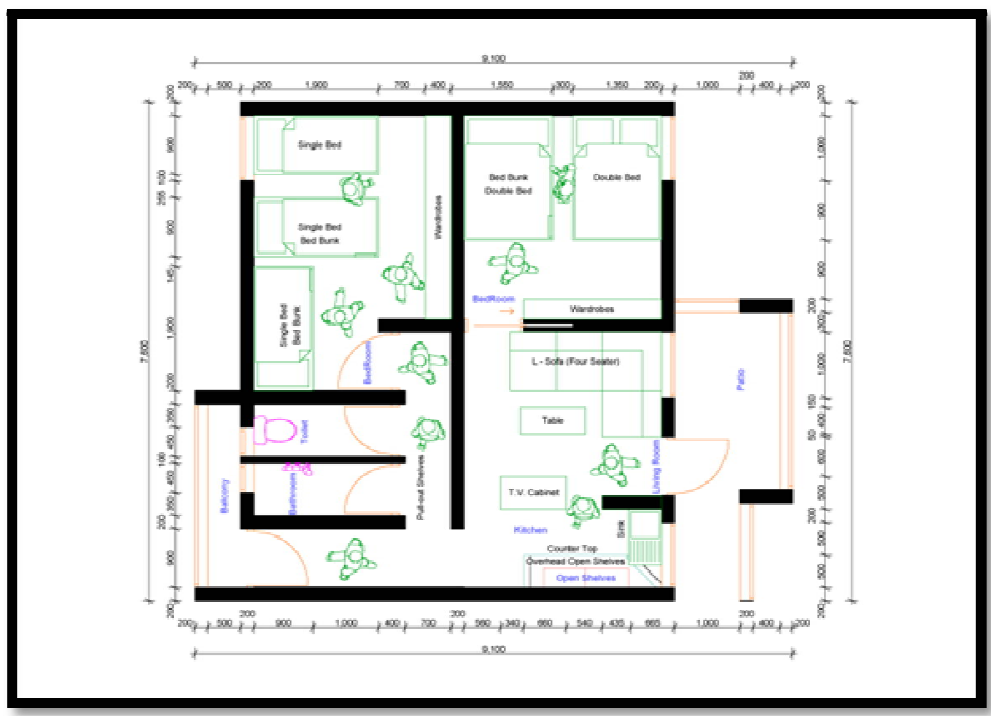

Figure 40: Two Bedroom House Floor Layout Plan Option Three (Author's Construct, 2018) 


\section{References}

i. Ahn, M., Beamish, J., Parrott, K., \& Emmel, J. (2015). Kitchen Space Planning in Small-Scale Houses. 83-94.

ii. Akyalçın, B. (2015). Investigating and Categorizing the Concept of Flexibility in Mobile Interior Spaces: The Case Study of Yacht Interior Spaces. 8-60.

iii. Boehland, J., \& Wilson, A. (2005). Small is Beautiful. Journal of Industrial Ecology, 286-287.

iv. Canepa, S. (2017). Living in a Flexible Space. Materials Science and Engineering, 1-10.

v. Cooper, R. D., \& Schindler, S. P. (2009). Business Reasearch Methods (10th Edition ed.). Tata McGraw Hill, New.

vi. Daily Nation. (2010a). Myth shattered: Kibera numbers fail to add up.

vii. Daily Nation. (2010b). How numbers game turned Kibera into 'the biggest slum in Africa'.

viii. Dash, K. (2003). Exterior and Interior Wall Materials. 146-147.

ix. Davis, S. (1997). The architecture of affordable housing.

x. Estaji, H. (2017). A Review of Flexibility and Adaptability in Housing Design. International Journal of Contemporary Architecture "The New ARCH" Vol. 4, No. 2, 37-49.

xi. Fay, R. (2005). Design Strategies For Affordable And Sustainable Housing. Environment Design Guide, 1-9.

xii. Frankfort-Nachmias, C., \& Nachmias, D. (1996). Research Methods in the Social Sciences. 5th edition.

xiii. Ganiyu, B. O., Haldenwang, R. \& Fapohunda, J. (2016). Developing sustainable housing for low income class in Western Cape province: Quality checks on South African government low-cost housing. 7th Annual SACQSP Research Conference on "Mapping the Future", (pp. 466-469). Western Cape.

xiv. GFSH-11, G. S. (2013, April). Project Linked Greenfield Subsidy Project Developments. Design and Construction of Houses, 4-9.

xv. Ghani, S., \& Lee , L. M. (1997). Low Cost Housing In Malaysia. Kuala Lumpur: Utusan Publications \& Distributor Sdn. Bhd. .

xvi. Gjakun, M. (2015). Flexibility and comfort in limited dwelling interior. Updated considerations regarding technical possibilities, functionality,trends and impacts on contemporary living since the period of 1970s, 38-190.

xvii. Grey, J. (2004). Trends in Kitchen design. Northwest Renovation: A Home Improvement Magazine.

xviii. Hammersley, M., \& Atkinson, P. (2007). Ethnography: Principles in practice. Routledge.

xix. Hanser, A. (2003). Assembly + Diassembly Of Interior Wall. 1-4.

xx. Hartany, J., \& Le, A. (n.d.). On flexible spaces and modularity.

xxi. Hoek-Smit, M. C. (2011). Government Policies and their Implication for Housing Finance.

xxii. Huchzermeyer, M. (2008). Slum upgrading in Nairobi within the housing and basic services market: a housing rights concern. Journal of Asian and African studies, 43(1), 19-39.

xxiii. Idrus, N., \& Ho, C. S. (2008). Affordable and quality housing through the low cost housing provision in Malaysia.

xxiv. Jones, T., Pettus, W., \& Pyatok, M. (1997). Affordable Family Housing. Mulgrave: The Images Publishing Group Pty Ltd.

xxv. Jones, T., Pettus, W., \& Pyatok, M. (1997). Good Neighbours: Affordable Family Housing. Mulgrave: The Images Publishing Group Pty Ltd.

xxvi. Kiiskinen, A. T. (2016). A Design Concept Proposal About Compact Living Units: Use Case For Student Housing. 7122.

xxvii. Knezo, A. (2016). Empowering Design through Flexible Personal Space. 32-37.

xxviii. Köhn, D., \& Von Pischke, J.D., J. D. (n.d.). Housing Finance in Emerging Markets. Springer.

xxix. MacDonald. (1996). Practical Solutions to Today's Housing Crisis. . New York: Whitney Library of Design.

xxx. Mugenda, M. O., \& Mugenda, G. A. (2003). Research Methods: Quantitative and Qualitative approaches.

xxxi. Peters, D. H., Elmendorf, A. E., Kandola, K., \& Chellaraj, G. (2000). Benchmarks for health expenditures, services and outcomes in Africa during the 1990s. Bulletin of the World Health Organization, 78, 761-769.

xxxii. Raviz, S. R., Eteghad, A. N., Guardiola, E. U., \& Aira, A. A. (2015). Flexible Housing: The Role Of Spatial Organization In Achieving Functional Efficiency. International Journal of Architectural Research, 65-75.

xxxiii. Roberts, M. (1990). Gender and Housing: The Impact of Design. Built Environment (1978-), Vol. 16, No. 4, Women and the Designed Environment, 257-268.

xxxiv. Robson, C., \& McCartan, K. (2016). Real world research. John Wiley \& Sons.

xxxv. Rosa, A., Flores, F., \& Bernard, C. (2012). The Kibera Soweto East Project. Nairobi, Kenya.

xxxvi. Schneider, T., \& Till, J. (2005). Flexible housing: the means to the end. Theory, 287-295.

xxxvii. Schneider, T., \& Till, J. (2007). Flexible Housing. 3-17.

xxxviii. Standard Media. (2010b). How numbers game turned Kibera into 'the biggest slum in Africa'.

xxxix. Susanka, S., \& Obolensky, K. (1998). A Blueprint for the Way We Really Live. Newtown: The Taunton Press Inc.

xl. Till, J., \& Schneider, T. (2005). Flexible housing: opportunities and limits. Theory, 157-164.

xli. UN-HABITAT. (2008a). Minutes of the Design and Redevelopment Committee Meeting.

xlii. UN-HABITAT. (2008b). Soweto East Redevelopment Proposal.

xliii. UN-HABITAT. (2008c). UN-HABITAT and the Kenya Slum Upgrading Programme Strategy Document. Nairobi.

xliv. Van Noppen, A. (2012). The ABC's of Affordable Housing in Kenya.

xlv. Ward, K. (2017). An Evidence-Based Approach to Designing Low-Income Housing Communities.

xlvi. Ziblim, A. (2013, August 15). The Dynamics of Informal Settlements Upgrading in South Africa. Informal Settlements Upgrading in South Africa, 1. 